\title{
Pozaustawowy kontratyp działania w ramach uprawnień wynikających z prawa do obrony w kontekście nowelizacji art. 233 § 1 Kodeksu karnego
}

\begin{abstract}
The work is devoted to the non-statutory justification of action in the scope of the right to defence, whose purpose was the exclusion of criminal responsibility for giving false testimony by a witness - the actual perpetrator - in his or her case. It was emphasised that the defence which heretofore resulted from Art. 182 and $183 \mathrm{kk}$ was insufficient for the witness. One discussed inter alia the legal basis of the justification, its constituent elements, one indicated the controversies which were caused by the concept of justification, and which to a great extent were associated with the violation, by the Supreme Court, of the constitutional principle of the tripartite division of powers and with the substantive and temporal limits of the right to defence which result both from the norms of international and domestic law.

One indicated the position of the representatives of the doctrine as to the concept of justification. Scholarship on the subject, even though it did not take a uniform stand in reference to the problem in question, basically discerned the necessity of the improvement of the situation of the witness - the actual perpetrator, who, testifying in his or her own case, would run the risk of self-incrimination. The considerations of the doctrine resulted in numerous alternative propositions de lege ferenda. In the work, one suggests to seek such a solution in the substantive approach to the nemo se ipsum accusare tenetur rule.

Then it was emphasised that the problem of justification once again became the subject of discussion owing to the amendment issued on 11 March 2016 about the modification of the act of law - The Code of Criminal Procedure and certain other acts of law Art. 233 $\S 1 \mathrm{a} \mathrm{kk}$. At that time one penalised the behaviour of a witness, who in fear of criminal liability to be faced by the witness or his relatives gives false testimony or conceals the truth. For the sake of recapitulation, one indicated that the amendment which was described above rendered the justification in question invalid, and the perpetrator who is heard in a court of law as a witness continues de lege lata to be entitled to use the right to refuse to answer the question from Art. $183 \S 1 \mathrm{kpk}$. One emphasised that the doctrine recurrently discerned the shortcomings of defence which result from Art. $183 \S 1 \mathrm{kpk}$. Above all the
\end{abstract}


institution from Art. $183 \S 1 \mathrm{kpk}$ was not intended for a witness - the actual perpetrator. Therefore, in the article, in order to realise the warranty nature of the entitlement in question one suggests that this admonishment should be rendered obligatory, so that every witness would be aware that the right exists and that he or she may exercise it.

Key words: instances of justification of action, the right to defence, giving false testimony, the actual perpetrator of a crime

Niniejsze opracowanie poświęcone zostało zagadnieniu kontratypu dla przestępstwa $\mathrm{z}$ art. $233 \$ 1$ k.k., tj. kontratypu działania w zakresie prawa do obrony. Kontratyp wprowadzony został do polskiego systemu prawnego kolejnymi orzeczeniami Sądu Najwyższego, w których zauważono istotny wpływ prawa do obrony na zakres odpowiedzialności karnej świadka za przestępstwo składania fałszywych zeznań, wyłączenie bezprawności oraz tendencję do poszerzania tego zakresu. Kontratyp miał na celu wyłączenie odpowiedzialności karnej za składanie fałszywych zeznań przez świadka-rzeczywistego sprawcę przestępstwa, dla którego ochrona wynikająca z art. 182 i 183 k.p.k. była niewystarczająca. Dla zobrazowania zagadnienia kontratypu zostaną omówione zatem motywy, jakimi kierował się Sąd Najwyższy, podejmując uchwały kształtujące ów kontratyp, charakter kontratypu, podstawa prawna, jego znamiona oraz zasygnalizowane poglądy judykatury i doktryny w tym zakresie. Instytucja kontratypu działania w zakresie prawa do obrony zostanie poddana ocenie w kontekście granic podmiotowych i czasowych samego prawa do obrony, w tym w świetle regulacji konstytucyjnej i prawa konwencyjnego, zasady nullum crimen sine lege, trójpodziału władzy. Wskazać również należy na znaczenie moralne i etyczne prezentowanego kontratypu. Omówienia wymagają, licznie zaprezentowane $\mathrm{w}$ literaturze, alternatywne względem kontratypu rozwiązania mające uchronić świadka-rzeczywistego sprawcę przestępstwa przed samodenuncjacją, jak na przykład rozwiązanie zakładające nowelizację art. 233 k.k. i uzupełnienie jego treści o nową klauzulę niekaralności, chroniącą sprawcę przestępstwa, który w obawie przed odpowiedzialnością karną składa fałszywe zeznania dotyczące jego czynu. Zaprezentowane zostanie brzmienie art. 233 § 1a k.k. wprowadzonego ustawą z dnia 11 marca 2016 r. o zmianie ustawy - Kodeks postępowania karnego oraz niektórych innych ustaw i argumentacja, jaka przyświecała ustawodawcy przy wprowadzaniu takiej regulacji do Kodeksu karnego, a także dwa opozycyjne stanowiska Prokuratora Generalnego i Pierwszej Prezes Sądu Najwyższego, wyrażone w opiniach do projektu nowelizacji tego artykułu. Ostatecznie omówienia wymaga znaczenie takiego rozwiązania dla dalszego funkcjonowania w praktyce kontratypu prawa do obrony, a w konsekwencji - jaka jest aktualna sytuacja prawna faktycznego sprawcy przestępstwa przesłuchiwanego w charakterze świadka w procesie karnym. 
Przyczynkiem do wypracowania w orzecznictwie kontratypu działania w zakresie prawa do obrony była sytuacja rzeczywistego sprawcy przestępstwa, który mógł wystąpić w postępowaniu karnym jednocześnie $\mathrm{w}$ roli świadka i zostać przesłuchany $\mathrm{w}$ takim charakterze $\mathrm{w}$ sprawie o czyn, który sam popełnił. Osoba taka jako świadek była zobowiązana do mówienia prawdy pod groźbą odpowiedzialności karnej. Ustawodawca nie przewidział dla rzeczywistego sprawcy przestępstwa przesłuchanego w charakterze świadka statusu odmiennego od „tradycyjnego" świadka przywileju w postaci prawa odmowy złożenia zeznań z uwagi na konieczność zeznawania w swojej sprawie, co mogło stawiać go w sytuacji przymusowej. Rzeczywisty sprawca przestępstwa-świadek znajdował się wówczas w sytuacji przymusowej, stawał bowiem przed następującym wyborem: złożyć zeznania prawdziwe i świadczyć przeciw sobie bądź złożyć zeznania fałszywe i narazić się na odpowiedzialność karną za czyn z art. $233 \$ 1$ k.k. ${ }^{1}$. Rzeczywisty sprawca przestępstwa przesłuchiwany $\mathrm{w}$ charakterze świadka w swojej sprawie miał do dyspozycji wyłącznie ochronę z art. 182 i art. 183 k.p.k., którą ocenić należy jako niedostateczną.

Art. $182 \S 1$ k.p.k. wprowadza ochronę stricte dla świadka-osoby najbliższej dla oskarżonego i ma na celu wyeliminowanie sytuacji, w której złożenie zeznań mogłoby skonfliktować świadka z oskarżonym, czy też w sposób negatywny wpłynąć na jego kontakty rodzinne. Zakres ograniczonej ochrony dotyczyć może tylko sytuacji, gdy świadek popełnia przestępstwo wspólnie z podejrzanym i jest dla niego osobą najbliższą. Wówczas współsprawca wezwany na przesłuchanie w charakterze świadka we własnej sprawie będzie mógł skorzystać z dobrodziejstwa art. 182 $\S 1$ k.p.k. jako osoba najbliższa dla podejrzanego i skutecznie uchylić się od obowiązku zeznawania. Ochrona wynikająca z art. 182 §1 k.p.k. jest niewystarczająca i bardzo wąska. Prawo do odmowy zeznań będzie również przysługiwało świadkowi, gdy w innej toczącej się sprawie uzyska status oskarżonego o współudział $\mathrm{w}$ przestępstwie objętym postępowa-

${ }^{1}$ Nabywane wraz z momentem popełnienia czynu zabronionego prawo do nieoskarżania samego siebie ma zagwarantować sprawcy, występującemu w jakiejkolwiek roli procesowej w postępowaniu przed organami władzy publicznej, że nie będzie on zmuszony świadczyć przeciwko sobie. W ten sposób chroniony będzie przed przypadkami samodenuncjacji. Denuncjacji bezpośredniej, gdy sprawca czynu zeznawałby w charakterze świadka przed organami uprawnionymi do prowadzenia przeciwko niemu postępowania karnego, oraz denuncjacji pośredniej, gdy sprawca czynu zeznawałby w charakterze świadka przed innymi organami państwa, na których, zgodnie z treścią art. 304 § 2 k.p.k., spoczywa obowiązek zawiadomienia o podejrzeniu popełnienia przestępstwa, o którym organy te posiadły wiadomość w związku z prowadzoną działalnością - M. BIELSKI: Wyłaczenie przestępności składania fałszywych zeznań $w$ związku z przysługujacym sprawcy czynu zabronionego prawem do obrony. CPKNP 2011, nr 15, s. 13. 
niem. Regulacja z art. $182 \S 3$ k.p.k. uzależnia jednak skorzystanie z prawa do odmowy złożenia zeznań od uzyskania statusu oskarżonego (rozumianego szeroko, a więc chodzi tu zarówno o oskarżonego sensu stricto, jak i podejrzanego $)^{2}$.

Zakres przedmiotowy art. $183 \S 1$ k.p.k. został natomiast wyraźnie ograniczony do odpowiedzi na pytanie, które mogłoby narazić świadka lub osobę dla niego najbliższą na odpowiedzialność za przestępstwo lub przestępstwo skarbowe. Uprawnienie z art. 183 §1 k.p.k. przysługuje wyłącznie świadkowi, a więc osobie, która - zgodnie $\mathrm{z}$ wiedzą organu ścigania - nie jest sprawcą czynu ani osobą określoną w art. 313 \$1 k.p.k., lecz osobą, która może posiadać wiadomości istotne dla ustalenia sprawcy lub okoliczności popełnionego przez niego przestępstwa ${ }^{3}$. Największe wątpliwości związane z ochroną wynikającą z art. 183 §1 k.p.k. wiążą się natomiast z prawidłowym pouczeniem świadka o przysługującym mu prawie. Zgodnie z treścią art. 191 \$2 k.p.k. organ procesowy ma obowiązek pouczyć świadka o możliwości uchylenia się od odpowiedzi na pytanie, gdy ujawnią się okoliczności objęte przepisem art. 183 §1 k.p.k. W procedurze karnej występuje jednak istotna odmienność na tle procedury administracyjnej, gdzie przepisy wyraźnie przewidują obowiązek uprzedzenia świadka o prawie nieudzielania odpowiedzi, która mogłaby narazić jego lub jego najbliższych na odpowiedzialność karną ${ }^{4}$. Okoliczności objęte treścią art. $183 \S 1$ k.p.k. mogą być znane organowi jeszcze przed przystąpieniem do przesłuchania (np. na skutek poczynienia konkretnych ustaleń dokonanych w postępowaniu, w którym świadek ma być przesłuchany lub w innym postępowaniu). Wówczas jest on zobowiązany pouczyć o tym świadka przed przesłuchaniem, nie zaś oczekiwać z takim pouczeniem do fazy zadawania pytań, czy też po prostu zwlekać z nim do uzyskania większej pewności, że pouczenie takie faktycznie winno nastąpić. Aby świadek mógł skorzystać z prawa odmowy zeznań lub uchylić się od odpowiedzi na pytanie, musi wiedzieć, iż może to uczynićs. Każda zwłoka powodować będzie, że prawo świadka staje się iluzoryczne. Co prawa w przypadku, gdyby do pouczenia takiego nie doszło, świadek nie podlegałby karze w oparciu o treść art. 233 § 3 k.p.k., jednak w świadomości organów ścigania pozostają wszystkie informacje dostarczone przez rze-

${ }^{2}$ Kodeks postępowania karnego. T. I. Red. D. ŚwIECKI. LEX Gamma 2018.

${ }^{3}$ Postanowienie SN z dnia 4 czerwca 2007 r., V KK 108/06, LEX nr 299215.

${ }^{4}$ Przepis art. 83 k.p.a. w $\$ 3$ wprost stanowi, iż przed odebraniem zeznania organ administracji publicznej uprzedza świadka o prawie odmowy zeznań i odpowiedzi na pytania oraz o odpowiedzialności za fałszywe zeznania.

${ }^{5}$ R.A. StefańsKi: Komentarz do art. 191 k.p.k., Komentarz do ustawy z dnia 6 czerwca 1997 r. Kodeks postępowania karnego (Dz.U. 1997 r., Nr 89, poz 555), w zakresie przepisów o postępowaniu przygotowawczym. LEX Prestige 2003. 
czywistego sprawcę przestępstwa podczas jego przesłuchania w charakterze świadka, również na jego niekorzyść.

Przymusową sytuację rzeczywistego sprawcy przestępstwa wzmacniał fakt, iż organ przesłuchujący dysponuje dostatecznymi instrumentami jak kara pieniężna, zatrzymanie i przymusowe doprowadzenie, aresztowanie, mającymi na celu wymusić na świadku stawiennictwo i złożenie zeznań. W związku z powyższym pojawiła się konieczność poszukiwania rozwiązania, które mogłoby w dostateczny sposób zabezpieczyć interesy rzeczywistego sprawcy przestępstwa przesłuchiwanego w charakterze świadka i ochronić przed zagrożeniem samodenuncjacją.

Dostrzegając sygnalizowany problem przymusowego położenia rzeczywistego sprawcy przestępstwa przesłuchiwanego w charakterze świadka, Sąd Najwyższy kolejnymi uchwałami - z dnia 20 czerwca 1991 r. ${ }^{6}$, 26 kwietnia 2007 r. ${ }^{7}$ i 20 września 2007 r. ${ }^{8}$, dotyczącymi odpowiedzialności świadka za składanie fałszywych zeznań, wypracował kontratyp dla przestępstwa z art. 233 \$1 k.k., tj. kontratyp prawa do obrony. Teza uchwały Sądu Najwyższego z dnia 20 września 2007 r. brzmiała następująco: „Nie popełnia przestępstwa fałszywych zeznań (art. 233 § 1 k.k.), kto umyślnie składa nieprawdziwe zeznania dotyczące okoliczności mających znaczenie dla realizacji jego prawa do obrony (art. 6 k.p.k.)”. Powyższe oznaczało, iż nie popełnia przestępstwa składania fałszywych zeznań, pomimo prawidłowego pouczenia o odpowiedzialności karnej za zeznanie nieprawdy lub zatajenie prawdy oraz pouczenia o prawie do odmowy odpowiedzi na pytanie, sprawca przestępstwa zeznający fałszywie co do okoliczności dotyczących jego czynu, jako że działał w ramach przysługujących mu uprawnień.

Kontratyp to wzorzec zespołu okoliczności, przy zaistnieniu których pewne zachowania człowieka kwalifikujemy jako niebezprawne, mimo że urzeczywistniają one znamiona ustawowej określoności czynu zabronionego, pojmowanej jako opis zachowania się typowo naruszającego normę sankcjonowaną ${ }^{9}$. Kontratyp jest zatem okolicznością wyłączającą

${ }^{6}$ Uchwała SN z dnia 20 czerwca 1991 r., I KZP 12/91, LEX nr 20459: „Nie jest dopuszczalne skazanie sprawcy fałszywych zeznań za przestępstwo określone w art. 247 § 1 k.k., jeżeli w postępowaniu karnym, w którym występował, jako oskarżony, złożył je uprzednio w charakterze świadka, co do okoliczności związanych z zarzucanym mu czynem".

${ }^{7}$ Uchwała SN z dnia 26 kwietnia 2007 r., I KZP 4/07, LEX nr 244459: „Nie ponosi odpowiedzialności karnej na podstawie art. 233 \$1 k.k. osoba, która przesłuchana została w charakterze świadka wbrew wynikającemu z art. $313 \S 1$ k.p.k. nakazowi przesłuchania jej jako podejrzanego”, zaprezentowanego w „uchwale kwietniowej”.

${ }^{8}$ Uchwała SN z dnia 20 września 2007 r., I KZP 26/07, LEX nr 298949.

9 J. MajewsKI: Czy znamię podmiotowe (subiektywne) jest jedna z cech konstytutywnych kontratypu?. W: Okoliczności wytączające bezprawność czynu. Materiaty IV Bielańskiego Kolokwium Karnistycznego. Red. J. MajewsKi. Toruń 2008, s. 40; Kontratypy to pewne abstrakcyjne typy określonych sytuacji, które nabierają sensu tylko wówczas, gdy skonfron- 
bezprawność czynu, jego prawną legalizacją, co powoduje, iż czyn taki nie narusza normy sankcjonowanej wysłowionej w przepisie, którego znamiona ten czyn wyczerpał. Wynika to $\mathrm{w}$ prostej linii z zasady niesprzeczności systemu prawnego ${ }^{10}$.

Kontratypy dzielą się na kontratypy ustawowe, a więc stypizowane, oraz kontratypy pozaustawowe, określane jako nieskodyfikowane ${ }^{11}$. Największe znaczenie mają kontratypy skodyfikowane, przewidziane w samym Kodeksie karnym (prawo do obrony, stan wyższej konieczności). Do okoliczności wyłączających bezprawność należą również uprawnienia zezwalające na dokonanie czynów uznanych przez prawo karne za zabronione, a dozwolone w oparciu o inne źródła ${ }^{12}$. Źródłami takich uprawnień mogą być inne przepisy, normy prawne, zasady prawa (zasada współżycia społecznego, wykonywanie pewnych funkcji i zawodów), a nawet zwyczaje (kontratypy wiosenne: prima aprilis, śmigus-dyngus) ${ }^{13}$. Ilekroć omawiamy kontratyp działania w granicach uprawnień, musimy wyodrębnić uprawnienia „prawne-ustawowe”, tj. takie, które wynikają wprost z przepisów prawa, oraz „pozaustawowe”, kształtowane w dro-

towane zostaną z typem czynu zabronionego, funkcją ich jest zaś neutralizowanie społecznie negatywnego ładunku. Kontratypy pozwalają więc na „dokonanie koniecznej korekty formalizmu zakazów karnych" - R. KRAJEwsKi: Kontratyp karcenia matoletnich po wprowadzeniu prawnego zakazu stosowania wobec nich kar cielesnych. Pal. 2012, nr 1-2, s. 49.

${ }^{10}$ T. KaczMareK: O tzw. okolicznościach „wyłaczajacych” bezprawność czynu. PiP 2008, nr 10, s. 27; Chociaż w Kodeksie karnym brak jest przepisu stanowiącego wprost o dopuszczalności kształtowania kontratypów pozaustawowych, to ich istnienie podyktowane jest koniecznością zapewnienia braku sprzeczności wewnątrz systemu prawnego (zasada niesprzeczności systemu prawnego) - I. GIERULA: Kontratyp działania w granicach szczególnych uprawnień i obowiazków. Pal. 2013, nr 1-2, s. 85.

${ }^{11}$ Katalog kontratypów pozaustawowych jest obszerny i otwarty w związku z „rozpoznawaniem przez doktrynę kolejnych kontratypów pozaustawowych, z których niektóre opierają się na utartej praktyce postępowania przez społeczeństwo, przy założeniu, że kontratypizacja jest społecznie opłacalna z uwagi na możliwość poświęcenia prawnego dobra i uszanowania przez prawo karne funkcjonujących w społeczeństwie reguł" R. KrajewsKi: Kontratyp karcenia..., s. 49-50; Według W. Woltera kontratypy rodzą się z potrzeb społecznych, a zasada ustawowego zamknięcia odnosi się jedynie do typów, nie zaś kontratypów, których krąg ustawowy może być węższy lub szerszy, jednak bez pretensji do wyczerpania pełnego zakresu - W sprawie społecznego niebezpieczeństwa $i$ bezprawności. NP 1956, nr 2, s. 74.

${ }^{12}$ H. PopŁawski: Działanie w granicach uprawnień i obowiazków jako okoliczność wyłaczająca bezprawność czynu. NP 1967, nr 12, s. 1614.

${ }^{13}$ J. WARYLEWsKi: Kontratypy wiosny. Pal. 199, nr 7-8, s. 24; W doktrynie można spotkać również pogląd przeciwny, zgodnie z którym uprawnienia lub obowiązki wyłączające bezprawność muszą być zawarte w aktach rangi ustawowej. Kontratyp nie może więc wynikać ze zwyczaju, nie może mieć również źródła w przepisach o charakterze wykonawczym, co wiąże się z zasadą państwa prawnego, zgodnie z którą organ państwa może działać tylko na podstawie przepisów prawa - I. GIERUla: Kontratyp działania..., s. 86. 
dze praktyki wymiaru sprawiedliwości lub będące wynikiem formułowania różnorakich koncepcji doktrynalnych w nauce prawa karnego ${ }^{14}$. Owe „uprawnienia” pojawiają się w prawie cywilnym (np. samopomoc), prawie administracyjnym (np. przymus bezpośredni), procedurze cywilnej, karnej, administracyjnej (np. przeszukanie, oględziny, zatrzymanie).

Kontratyp działania w zakresie prawa do obrony był kontratypem pozaustawowym, nieskodyfikowanym i pozakodeksowym oraz miał na celu wyeliminowanie kolizji, jaka zachodzi w umyśle sprawcy pomiędzy koniecznością zeznawania prawdy jako świadek, a prawem nieobciążania samego siebie. Kontratyp przesądził o prymacie prawa do obrony nad dobrem wymiaru sprawiedliwości, ale również miał zapobiegać denucjacji bezpośredniej, jak i pośredniej przez faktycznego sprawcę przestępstwa. Zdaniem Sądu Najwyższego i zwolenników koncepcji kontratypu działania w zakresie uprawnień opierał się on na normach rangi ustawowej oraz częściowo był stypizowany w przepisach prawa ${ }^{15}$. Źródłem tego kontratypu był, jak wskazał Sąd Najwyższy, art. 42 ust. 2 Konstytucji RP, art. 6, 74 $\S 1$ i art. $175 \S 1$ Kodeksu postępowania karnego, tym samym kontratyp odnosił się wprost do uprawnień wskazanych w przepisach prawa i jest efektem interpretacji systemowej. J. Potulski wypowiedział się wręcz, że jest to raczej wyraz kombinacji przepisów, poglądów doktryny, orzecznictwa sądów polskich i ETPC, czy też nawet ustalonej praktyki ${ }^{16}$.

Próba uchwycenia znamion omawianego kontratypu ${ }^{17}$ prowadzi do wniosku, iż podmiotem omawianej sytuacji kontratypowej będzie faktyczny sprawca przestępstwa, w tym w szczególności zajmujący pozycję

${ }^{14}$ J. Warylewski wyjaśnił, iż „mówiąc o kontratypach pozaustawowych mamy na myśli te, których znamiona nie zostały w żadnej ustawie, w całości (wyczerpująco) określone, co nie przeszkadza temu, że w przypadku znacznej części kontratypów pozaustawowych możemy w ustawach znaleźć część ich znamion, a w każdym razie pewne uzasadnienie dla ich funkcjonowania" - Zasada ustawowej określoności przesłanek odpowiedzialności karnej a kontratypy pozaustawowe. W: Okoliczności wyłączające bezprawność czynu..., przypis nr 3; J. Warylewski opowiadał się za koniecznością wprowadzania do systemu prawa karnego licznych kontratypów, jeżeli podyktowane jest to dynamiką zmian w zakresie warunków życia, usprawiedliwionych potrzeb i oczekiwań społecznych - J. WARYLEWSKI: Prawo karne. Część ogólna. Warszawa 2004, s. 21.

${ }^{15}$ I. GIERULA: Kontratyp dziatania..., s. 88.

${ }^{16}$ J. PотULSKI: Glosa do uchwaty SN z dnia 20 kwietnia 2007 r., I KZP 4/07. GSP 2008, nr 3, s. 114; I. Gierula wskazuje, iż kontratyp nie znajduje pełnej typizacji w konkretnym przepisie prawa, a w konsekwencji powstają wątpliwości, czy należy do grupy kontratypów działania w granicach uprawnień i obowiązków, czy też stanowi swoisty rodzaj kontratypu - I. GieRULA: Kontratyp działania..., s. 88.

${ }^{17}$ H. RaJzman podkreślał potrzebę „stypizowania” kontratypów, tzn. ścisłego opisania granic, poza które sędziemu rozpoznającemu przypadek mieszczący się w sytuacji w ogólnym zarysie analogicznej wyjść nie wolno - H. RaJzMAN: Zagadnienie „kontratypów” $w$ projekcie kodeksu karnego PRL. PiP 1963, nr 3, s. 513. 
osoby podejrzanej sensu stricto ${ }^{18}$ czy osoby podejrzanej sensu $\operatorname{largo}^{19}$. Można pokusić się również o stwierdzenie, iż będzie to osoba, która pozostaje w błędnym przekonaniu, że dopuściła się przestępstwa, co ściśle wiąże się ze stroną podmiotową kontratypu ${ }^{20}$. Tylko bowiem takie osoby mogą świadomie, umyślnie dążyć, poprzez złożenie fałszywych zeznań dotyczących popełnionego czynu zabronionego, do uniknięcia odpowiedzialności karnej. Osoby te muszą posiadać w procesie formalnie status świadka i w takim charakterze składać zeznania.

„Stroną podmiotową" kontratypu ${ }^{21}$ należy określić świadomość sprawcy sytuacji kontratypowej. Jak wskazał Sąd Najwyższy w wyroku z dnia 30 grudnia 1972 r.: „Niezbędnym elementem podmiotowym obrony koniecznej jest, aby akcja broniącego się wynikała ze świadomości, że odpiera on zamach, i podyktowana była wolą obrony. Ten podmiotowy element działania w obronie koniecznej ułatwia rozgraniczenie rzeczywistych działań obronnych od społecznie negatywnych aktów zemsty, samosądu lub chuligaństwa"22. Przekładając powyższe na grunt poza-

${ }^{18} \mathrm{Za}$ osobę podejrzaną sensu stricto należy uznać osobę, co do której istniejące faktyczne dane wskazują na uzasadnione podejrzenie popełnienia przestępstwa, jednak stopień podejrzenia jest niższy niż dostatecznie uzasadniony.

${ }_{19}$ Osobą podejrzaną sensu largo (faktycznie podejrzanym) będzie osoba podejrzana, wobec której istniejące $\mathrm{w}$ chwili wszczęcia śledztwa lub zebrane w jego toku dane uzasadniają dostatecznie podejrzenie, że to ona popełniła czyn, a mimo to wbrew brzmieniu art. 313 k.p.k. nie przedstawiono jej zarzutów.

${ }^{20} \mathrm{Błąd} \mathrm{co} \mathrm{do} \mathrm{kontratypu} \mathrm{funkcjonuje} \mathrm{niezależnie} \mathrm{od} \mathrm{tego,} \mathrm{czy} \mathrm{mamy} \mathrm{do} \mathrm{czynienia}$ z kontratypem ustawowym czy pozaustawowym, chociaż oczywiście w drugim przypadku może powstać wątpliwość, jakie znamiona charakteryzują daną okoliczność kontratypową i czy błąd dotyczy któregokolwiek z tych znamion - J. GIEZEK, N. KŁączYŃsKA, G. Łabuda. W: Kodeks karny. Część ogólna. Komentarz. Red. J. GIEZeK. 2012, LEX Prestige 2012; G. Labuda, T. RazowsKi, P. Kardas: Kodeks karny skarbowy. Komentarz. Kraków 2010, s. 240; M. Pawełek wskazał, iż skoro mamy do czynienia z kontratypem, to zastosowanie musi znaleźć art. 29 k.k., który reguluje kwestię błędu co do kontratypu. Art. 29 k.k. znajdzie zastosowanie wówczas, gdy świadek składa fałszywe zeznania, pozostając w błędnym, acz uzasadnionym okolicznościami przekonaniu, że popełnił przestępstwo i wobec tego korzysta z prawa do obrony. Jego działanie (mówienie nieprawdy) musi być jednak kierunkowe, tzn. świadomie nakierowane na realizację prawa do obrony - M. PAwEŁEK: Urojone prawo do obrony a odpowiedzialność za fałszywe zeznania. Prok. i Pr. 2009, nr 4, s. 152.

${ }^{21} \mathrm{Za}$ tzw. znamieniem subiektywnym jako immanentną cechą kontratypów opowiedzieli się przedstawiciele polskiej doktryny jak: A. WĄseK: Problematyka kontratypów przy przestępstwach nieumyślnych. Pal. 1988, nr 10, s. 61 i nast.; A. MAREK: Obrona konieczna w prawie karnym. Warszawa 1979, s. 64-66; J. GIEZEK: Glosa do postanowienia SN z 3 stycznia 2002 r., IV KKN 635/97. PiP 2002, nr 11, s. 106-110 oraz judykatura: wyrok SN z dnia 3 stycznia 2002 r., IV KKN 635/97, LEX nr 52282; wyrok SN z dnia 19 marca 1982 r., III KR 31/82, LEX nr 17432.

${ }^{22}$ Wyrok SN z dnia 30 grudnia 1972 r., Rw 1312/72, LEX nr 18582. 
ustawowego kontratypu działania w granicach prawa do obrony, z wypełnieniem znamienia subiektywnego kontratypu będziemy mieli do czynienia, jeżeli świadek zeznając nieprawdę czy zatajając prawdę będzie działał z wolą, chęcią uniknięcia odpowiedzialności karnej, czyli świadomością, iż te konkretne fałszywe zeznania mają uchronić go przed poniesieniem odpowiedzialności za własny czyn. Oczywiście powyższe nie jest równoznaczne z tym, że świadek musi zdawać sobie sprawę, że te okoliczności, w których działa, wypełniaja pojęcie kontratypu działania w charakterze uprawnień, ale niewątpliwie fałszywe zeznania musi on składać w jednym, konkretnym celu. To znaczy, że brak świadomości, iż kłamie się, aby uniknąć odpowiedzialności karnej, nie wyłączy odpowiedzialności karnej za czyn z art. 233 \$ 1 k.k. Powyższe pozostaje w związku ze świadomością sprawcy, czy też przekonaniem, że popełnił on czyn zabroniony.

Znamieniem przedmiotowym omawianego kontratypu będą zeznania, względnie oświadczenia, czyli relacje świadka o zaobserwowanych przez niego zdarzeniach. Treść fałszywych zeznań musi odnosić się do okoliczności mających znaczenie dla ustalenia odpowiedzialności karnej świadka, czyli musi być istotna z punktu widzenia jego prawa do obrony. W pozostałym zakresie, a więc co do okoliczności niemających znaczenia dla jego odpowiedzialności karnej, świadek poniesie odpowiedzialność karną na podstawie art. $233 \S 1$ k.k. Podawane okoliczności muszą dotyczyć odpowiedzialności samego świadka. Kontratyp nie wyłączy odpowiedzialności karnej za złożone fałszywe zeznania, jeżeli miałyby one służyć ochronie innej osoby, np. osoby najbliższej, przed odpowiedzialnością karną. Ostatecznie podawane przez świadka fałszywe informacje muszą zmierzać do uniknięcia odpowiedzialności karnej, nie zaś np. do odpowiedzialności cywilnej czy za wykroczenia.

Koncepcja kontratypu działania w ramach uprawnień wynikających z prawa do obrony została wielokrotnie powtórzona w orzeczeniach Sądu Najwyższego ${ }^{23}$ oraz zaakceptowana i stosowana w orzecznictwie sądów powszechnych ${ }^{24}$.

Przedstawiciele polskiej nauki prawa karnego materialnego i procesowego podzielili się w swoich poglądach co do zasadności stanowiska pre-

${ }^{23}$ Wyrok SN z dnia 24 kwietnia 2007 r., IV KK 127/07, LEX nr 293375; postanowienie SN z dnia 22 września 2008 r., IV KK 241/08, LEX nr 464981; wyrok SN z dnia 12 lutego 2009 r., III K 339/08, LEX nr 486545; wyrok SN z dnia 30 czerwca 2009 r., V KK 25/09, LEX nr 512071; wyrok SN z dnia 17 października 2012 r., IV KK 99/12, LEX nr 1231601; wyrok SN z dnia 22 listopada 2012 r., V KK 265/12, LEX nr 1231653; wyrok SN z dnia 21 listopada 2014 r., III KK 348/14, LEX nr 1545153.

${ }^{24}$ Wyrok SA w Łodzi z dnia 19 czerwca 2001 r., II AKa 74/01, LEX nr 54981; wyrok SO w Białymstoku z dnia 19 marca 2009 r., VIII Ka 63/09, LEX nr 1294025; wyrok SO w Siedlcach z dnia 12 lipca 2013 r., II Ka 278/13, LEX nr 1717902. 
zentowanego przez Sąd Najwyższy na dwie opozycyjne grupy. Pomijając dokładną analizę poszczególnych stanowisk, wyróżnić można przeciwników tego stanowiska, którzy prezentowali pogląd, iż treść art. $183 \S 1$ k.p.k. i art. $233 \S 3$ k.p.k. dostatecznie zabezpiecza interesy świadka przed samooskarżeniem $\mathrm{w}$ toku składanych zeznań i pozwala realnie zrealizować założenia zasady nemo se ipsum accusare tenetur ${ }^{25}$, oraz zwolennków, którzy natomiast stanęli na stanowisku, iż oddziaływanie prawa do obrony oraz prawa do nieoskarżania samego siebie sięga znacznie dalej, wyłączając tym samym odpowiedzialność świadka za składanie fałszywych zeznań w sytuacji, gdyby miał dostarczyć informacji przeciwko samemu sobie, narażając się tym samym na odpowiedzialność karną. Świadek-osoba podejrzana korzysta bowiem z prawa do obrony, a więc działa w granicach uprawnienia, tj. korzysta $z$ kontratypu wyłączającego bezprawność takiego zachowania ${ }^{26}$.

Oceniając omawiany kontratyp pod kątem źródeł prawa do obrony, jego granic podmiotowych i temporalnych, podzielić należy pogląd, iż koncepcja kontratypu działania w zakresie uprawnień nie może znaleźć oparcia ani w normach Konstytucji RP ani Kodeksu postępowania karnego, a tym samym stać się okolicznością wyłączającą odpowiedzialność karną. Pojęcie „każdy” użyte w art. 42 ust. 2 Konstytucji P. Wiliński poleca rozumieć w znaczeniu, jakie nadaje mu art. 37 Konstytucji, tj. „każdy" to ten, kto znajduje się pod władzą Rzeczpospolitej Polskiej, korzysta $\mathrm{z}$ wolności i praw zapewnionych w Konstytucji ${ }^{27}$. Nie może ujść uwadze, iż przepis art. 42 ust. 2 Konstytucji zawiera określenie „każdy, przeciw komu", w ten sposób zawężając grono podmiotów korzystających

${ }^{25}$ M. WARChOŁ: Glosa do uchwaty SN z dnia 26 kwietnia 2007 r., I KZP 4/07. WPP 2007, nr 3, s. 109; R.A. STEFAŃSKI: Glosa do uchwały SN z dnia 26 kwietnia 2007 r., I KZP 4/07. OSP 2008, nr 3, s. 191; A. WĄSEK: Glosa do uchwaty SN z dnia 20 czerwca 1991 r., I KZP 12/91. WPP 1992, nr 3-4, s. 74-75, 77.

${ }^{26}$ L. PAPRZYCKI: Glosa do uchwaty SN z dnia 20 czerwca 1991, I KZP 12/91. Pal. 1992, nr 1-2, s. 95; Z. DodA, A. GABERLE: Dowody w procesie karnym. Orzecznictwo Sadu Najwyższego. Komentarz. T. I. Warszawa 1995, s. 77; Z. KwiATKowsкi: Glosa do uchwały SN $z$ dnia 20 czerwca 1991 r., I KZP 10/91. PS 1992, nr 7-8, s. 134; M. FILAR: Glosa do uchwaty SN z dnia 20 września 2007 r., I KZP 26/2007. OSP 2008, nr 4, s. 307; M. SIwEK: Glosa do uchwaty SN z dnia 26 kwietnia 2007 r., I KZP 4/2007. PS 2008, nr 3, s. 131; R. KMIECIK: Glosa do uchwaty SN z dnia 20 września 2007 r., I KZP 26/2007. PiP 2007, nr 12, s. 161; A. LACH: Glosa do uchwaty SN z dnia 20 września 2007 r., I KZP 26/2007, LEX Prestige; J. PотULsкi: Glosa do uchwaty..., s. 111; D. GRUszeCKA: Zasięg prawa do obrony w kontekście odpowiedzialności za fatszywe zeznania. CzPKiNP 2010, nr 2, s. 139.

${ }^{27}$ P. WiLIŃski: Proces karny $w$ świetle konstytucji. Warszawa 2011, s. 88; orzeczenie TK z dnia 20 października 1992 r., K 1/92, LEX nr 25221; wyrok TK z dnia 26 listopada 2003 r., SK 22/02, OTK ZU nr 9/A/2003, poz. 97; wyrok TK z dnia 3 listopada 2004 r., K 18/03, LEX nr 133746; wyrok TK z dnia 8 lipca 2003 r., P 10/02, OTK ZU nr 6/A/2003, poz. 62; wyrok TK z dnia 8 listopada 2004 r., K 38/03, LEX nr 133752. 
z tego prawa. Początkiem postępowania karnego, chwilą jego wszczęcia, $\mathrm{w}$ którym rozstrzyga się o winie i karze, jest w praktyce przedstawienie zarzutów, a końcem - nie tylko wydanie prawomocnego wyroku, ale i postępowanie wykonawcze ${ }^{28}$. Zasadę prawa do obrony w polskim procesie karnym statuuje przede wszystkim art. 6 k.p.k., $74 \$ 1$ k.p.k., 175 k.p.k. Art. 6 wskazuje, iż oskarżonemu przysługuje prawo do obrony, zaś art. 71 §1-3 wyjaśnia, kogo należy rozumieć jako podejrzanego i oskarżonego oraz rozszerza zastosowanie wszystkich przepisów, które posługują się pojęciem oskarżonego również na podejrzanego. Kwestia podmiotowych i temporalnych granic prawa do obrony nie budzi większych wątpliwości wśród komentatorów Konstytucji $\mathrm{RP}^{29}$. Wątpliwości wysuwali natomiast przedstawiciele doktryny $\mathrm{z}$ dziedziny prawa karnego procesowego przy okazji, a raczej w celu uzasadnienia powstałej koncepcji działania w zakresie prawa do obrony jako okoliczności wyłączającej odpowiedzialność karną za składanie fałszywych zeznań przez świadka. Tożsame granice prawa do obrony wyznacza art. 14 ust. 3 lit. b oraz d-e Międzynarodowego Paktu Praw Obywatelskich i Politycznych ${ }^{30}$. Rozumienie prawa do obrony $\mathrm{w}$ tradycyjnym kształcie pozostaje również w zgodzie z art. 6 ust. 3 lit. c Europejskiej Konwencji Praw Człowieka i Podstawowych Wolności ${ }^{31}$. W wyroku Serves c/a Francja ${ }^{32}$ Trybunał potwierdził: „Koncepcja „oskarżenia w wytoczonej sprawie karnej” (art. 6 Konwencji) jest autonomiczna, należy ją stosować w rozumieniu Konwencji, a nie jedynie w rozumieniu prawa krajowego. Może zatem być zdefiniowana jako „oficjalne powiadomienie jednostki przez uprawniony organ o domniemaniu, że popełniła ona przestępstwo", która to definicja wiąże się z kryterium, czy „sytuacja (podejrzanego) uległa znacznej zmianie”.

W uchwale z dnia 20 września 2007 r. Sąd Najwyższy położył nacisk na korzystanie z przysługującego z mocy Konstytucji prawa do obrony,

\footnotetext{
${ }_{28}^{28}$ B. BanaszaK: Konstytucja Rzeczpospolitej Polskiej. Komentarz. Warszawa 2009, s. 232.

${ }^{29}$ P. SARNECKI stwierdził, że w ujęciu konstytucyjnym prawo do obrony oznacza „możność podejmowania wszelkich działań niesprzecznych z prawem, które w przekonaniu osoby poddanej temu postępowaniu mogą potwierdzić jego wersje zdarzeń (...) oraz jego niewinności lub występowanie określonego rodzaju winy" - P. SARNeCKI: Artykut 42. W: Konstytucja RP. Komentarz. T. III. Red. L. GARLICKI. Warszawa 2003, s. 2; „Nie ulega wątpliwości, że prawo do obrony musi przysługiwać jednostce w każdej z tych faz postępowania. Jednocześnie zakres uprawnień wchodzących w skład prawa do obrony może się różnić na poszczególnych etapach i być adekwatny do ich istoty" - M. SAFIAN, L. BoseK: Konstytucja RP. T. I: Komentarz do art. 1-86. Warszawa 2016, LexisNexis; B. BonAszAK: Konstytucja Rzeczypospolitej Polskiej. Komentarz. Warszawa 2012, LexisNexis.

${ }^{30}$ Dz.U. 1977, nr 38, poz. 167.

${ }^{31}$ Dz.U. 1993, nr 61, poz. 284.

${ }^{32}$ Wyrok ETPC z dnia 20 października 1997 r., Serves c/a Francja, 20225/92, LEX nr 79567.
} 
sugerując $w$ ten sposób, że art. 42 ust. 2 Konstytucji RP podlega bezpośredniemu stosowaniu. Zgodnie z art. 8 ust. 2 Konstytucji przepisy stosuje się bezpośrednio, chyba że Konstytucja stanowi inaczej33. Jednocześnie zasada ta nie ma charakteru absolutnego. W końcowych słowach art. 8 ust. 2 Konstytucji zastrzeżono istnienie wyjątków od tej zasady, wprowadzając sformułowanie: „chyba że Konstytucja stanowi inaczej”. Jeśli chodzi o sam termin „bezpośrednie stosowanie konstytucji”, to w orzecznictwie Sądu Najwyższego, w tym w uzasadnieniach jego rozstrzygnięć, brak jest szerszej refleksji w kwestii tego, czym jest owe „bezpośrednie stosowanie konstytucji”. Termin ten jest najczęściej rozumiany intuicyjnie $^{34}$. Jak pisze A. Łabno-Jabłońska, bezpośrednie stosowanie Konstytucji polega na wydawaniu aktów indywidualnych i konkretnych wyłącznie na podstawie norm konstytucyjnych. Zasada bezpośredniego stosowania konstytucyjnych praw i wolności jednostki oznacza, że pewne kategorie praw jednostki, a więc prawa uregulowane w konstytucji, są stosowane w taki właśnie sposób ${ }^{35}$. W związku z art. 8 ust. 2 Konstytucji A. Mączyński odróżnia dwa rodzaje jej przepisów: bezpośrednio stosowane i inne. Jednocześnie wskazuje, iż kryterium decydującego o zaliczeniu danego przepisu do jednej z tych grup należy poszukiwać $\mathrm{w}$ jego treści. Wskazuje na dwie okoliczności uzasadniające zaliczenie przepisu do drugiej grupy. Po pierwsze, gdy przewiduje on wydanie ustawy (nie zawsze jednak wzmianka o ustawie wyłącza możliwość bezpośredniego stosowania Konstytucji, np. w sytuacji, gdy przepis konstytucyjny wyraża zasadę, ale dopuszcza możliwość wyjątków ustawowych od niej, to w zakresie owej zasady jest stosowany bezpośrednio, a wyjątek musi mieć oparcie w ustawie), po drugie, gdy przepis Konstytucji ujęty został w sposób uniemożliwiający bezpośrednie stosowanie ${ }^{36}$. K. Działocha wyjaśnił, iż ze sto-

${ }^{33}$ K. DziaŁocha wskazuje, iż pojęcie „bezpośrednie” stosowanie Konstytucji zastępuje się pojęciem „samoistne” stosowanie Konstytucji, co jest nawiązaniem do pojęcia norm „samowykonalnych” w rozumieniu doktryny prawa międzynarodowego”, lecz nie przeciwstawia się zasadzie znaczenia tych dwóch norm - Zasada bezpośredniego stosowania konstytucji $w$ dziedzinie wolności i praw obywateli. W: Obywatel - jego wolności i prawa. Zbiór studiów przygotowanych z okazji 10-lecia urzędu RPO. Red. B. Oliwa-RADZIKOwsKA. Warszawa 1998, s. 30.

${ }^{34}$ W. SANETRA: Bezpośrednie stosowanie Konstytucji RP w orzecznictwie Sądu Najwyższego. W: Bezpośrednie stosowanie Konstytucji Rzeczypospolitej Polskiej. Red. K. DzIaŁocha. Warszawa 2005, s. 53.

35 A. ŁaBno-JabŁońsKa: Zasada bezpośredniego obowiqzywania konstytucyjnych praw $i$ wolności jednostki analiza prawnoporównawcza. W: Podstawowe prawa jednostki $i$ ich sądowa ochrona. Red. L. WiśnIEWSKI. Warszawa 1997, s. 64.

36 Takie stanowisko godzi i łączy dwa skrajne poglądy. Jeden, prezentowany m.in. przez B. Banaszaka, zgodnie z którym bezpośrednie stosowanie konstytucji zostaje wyłączone w każdym przypadku, gdy konstytucja odsyła uregulowanie jakiejś materii w mniejszym czy większym zakresie do ustawy (B. BANASzaK: Prawo konstytucyjne. Warszawa 2001, 
sowaniem bezpośrednim „samoistnym” mamy do czynienia w przypadku spełnienia warunku konkretności i precyzji (jednoznaczności) przepisów Konstytucji, by tylko na tej podstawie, a więc bez potrzeby rozwijania tych przepisów w ustawie, możliwe było rozstrzygnięcie indywidualnej sprawy. Jednocześnie, jak wskazuje autor, przepisów spełniających ten wymóg jest bardzo mało w Konstytucji, a więc i przypadki tak rozumianego bezpośredniego stosowania będą rzadkie ${ }^{37}$. Jak pisze S. Wronkowska, nigdy nie było przedmiotem sporu, że np. przepisy kształtujące takie organy i instytucje jak Sejm, Senat, Radę Ministrów, Najwyższą Izbę Kontroli, Krajową Radę Sądownictwa stosuje się bezpośrednio ${ }^{38}$. Biorąc pod uwagę powyższe oraz treść art. 42 ust. 2 Konstytucji RP, wskazać należy, iż zawiera on ogólne pojęcie „prawa do obrony”, wprawdzie uszczegółowione w pewnym stopniu treścią zdania 2 art. 42 ust. 2, jednak, jak pisze R. Koper, oznaczać to musi obowiązek wprowadzenia - zwłaszcza w normach ustawowych - stosownych gwarancji prawnych. Koniecznym staje się, z uwagi na duży stopień ogólności, dokonanie implementacji ustawowej ${ }^{39}$. Aby powyższa norma mogła być zastosowana, wymaga konkretyzacji i rozwinięcia w ustawie zwykłej, bez niej bowiem nie można - tylko na podstawie przepisu konstytucyjnego - ustalić normy dostatecznie określonej, aby uczynić z niej podstawy wydania normy konkretnej i jednostkowej.

Podsumowując poczynione powyżej rozważania, kategorycznie należy stwierdzić, iż w aktualnym stanie prawnym, uwzględniając zarówno prawo krajowe, jak i konwencyjne, prawo do obrony przysługuje najwcześniej od momentu przedstawienia zarzutów i brak jest podstaw dla rozszerzenia jego granic na świadka, w tym rzeczywistego sprawcę przestępstwa, zeznającego w swojej sprawie czy w innym postępowaniu karnym, bądź też innym postępowaniu przewidzianym przez ustawę. Skoro prawo do obrony przysługuje wyłącznie oskarżonemu (podejrzanemu),

s. 99-100) oraz drugi (J. TrzcińsKi: Funkcja prawna konstytucji socjalistycznej. Wrocław 1978, s. 85), który zakłada, iż decydujące znaczenie dla uznania normy konstytucyjnej za samowykonalną ma jej konkretność i precyzja; R. KOPER: Jawność rozprawy głównej a ochrona prawa do prywatności $w$ procesie karnym. Warszawa 2010, s. 201; Chodzi o sytuacje, w których przepis ten, „nawet wraz z innymi przepisami konstytucji, nie wystarcza do skonstruowania normy mogącej służyć za podstawę rozstrzygnięcia sprawy sądowej, jego treść jest bowiem zbyt ogólna, by mogła jednoznacznie wyznaczyć treść decyzji stosowania prawa - A. MĄczYŃsKi: Bezpośrednie stosowanie Konstytucji przez sądy. PiP 2000, nr 5, s. 7.

${ }^{37}$ K. DziaŁocha: Bezpośrednie stosowanie Konstytucji RP (stan doktryny prawa). W: Bezpośrednie stosowanie Konstytucji Rzeczypospolitej Polskiej. Red. IDEM. Warszawa 2005, s. 19.

${ }^{38}$ S. WronkowsKa: W sprawie bezpośredniego stosowania Konstytucji. PiP 2001, nr 9, s. 7.

${ }^{39}$ R. KoPER: Jawność rozprawy głównej..., s. 202. 
to kontratyp oparty na tym uprawnieniu nie może mieć szerszego zastosowania aniżeli samo prawo. Ewentualne granice kontratypu mogą być tożsame z granicami prawa do obrony, a wówczas istnienie kontratypu byłoby zbędne, skoro ewentualne kłamstwo oskarżonego jest dopuszczalne poprzez przysługujące mu, w związku z zajmowaną pozycją w procesie, gwarancje procesowe. Nawet jeżeli zakładać szersze granice prawa do obrony (hipotetycznie), pojawiają się inne wątpliwości, dotyczące w ogóle koncepcji kontratypu.

Zgodnie z poglądem doktryny kontratyp działania w granicach uprawnień, jako zgoda na nieodpowiedzialność, wiąże się z potrzebą zapewnienia spójnego systemu prawnego i ma na celu eliminację ewentualnych sprzeczności przy założeniu, że cokolwiek jest w jakiejkolwiek ustawie dozwolone lub nakazane, to jednocześnie nie może być zakazane pod groźbą kary. Okoliczności wyłączające bezprawność mogą pochodzić z obszaru innych gałęzi prawa, np. cywilnego czy administracyjnego, wówczas ich zakres jest suwerennie ustalony przez gałęzie prawa, z których pochodzą, na podstawie właściwych dla tych gałęzi metod i kryteriów, będąc bez zastrzeżeń przyjmowane w prawie karnym ${ }^{40}$. Wobec powyższego fakt bezprawności określonego zachowania, wynikający z określonej normy prawa karnego materialnego, nie przesądza automatycznie o absolutnej bezprawności takiego zachowania. Wyrażane są poglądy, że prawo karne materialne ma charakter subsydiarny i nie może niweczyć uprawnień wynikających z innych aktów rangi ustawowej. Może zdarzyć się więc, że inny przepis prawa rangi ustawowej będzie zezwalał na zachowania penalizowane przez normę karnomaterialną. Kontratyp ma na celu taką sprzeczność rozstrzygnąć. Ową sprzeczność upatruje się w sytuacji, gdy świadek z jednej strony obarczony jest obowiązkiem mówienia prawdy, do czego obliguje go treść art. 233 kk, z drugiej zaś - z faktu popełnienia czynu, na okoliczność którego zeznaje - ma prawo nieobciążania samego siebie (art. $74 \$ 1 \mathrm{w}$ zw. z art. 6 k.p.k. $)^{41}$.

40 „Prawo karne ma charakter akcesoryjny właśnie przede wszystkim w zakresie sytuacji wyłączających bezprawność, bowiem jego charakter nie pozwala na przyjęcie bezprawności czynu w wypadku, gdy istnieje zezwolenie $\mathrm{w}$ jakiejkolwiek pozakarnej gałęzi prawa" - Z. JęDRZEJEWSKI: Nullum crimen sine lege i kontratypy a zasada jedności porzadku prawnego (jednolitej bezprawności). IN 2011, nr 1, s. 25.

${ }^{41}$ Jak pisze S. Stypuła, usunięcie takiej sprzeczności nie jest możliwe przy użyciu wykładni językowej tych przepisów. Należy więc na to zagadnienie spojrzeć z punktu widzenia całego systemu prawnego, w szczególności zaś funkcjonujących zasad. Dodał, iż odstąpienie od wykładni językowej przepisów jest możliwe, gdy wykładnia ta prowadzi do absurdu, rażąco niesprawiedliwych lub irracjonalnych konsekwencji bądź też po jej zastosowaniu nie udało się uzyskać jasnego znaczenia interpretowanych norm. Wtedy dopuszczalna jest wykładnia systemowa, która tutaj znajdzie zastosowanie - S. STYPUŁA: 
Nie sposób nie zgodzić się, że takowa sytuacja, w której znajduje się świadek, ma charakter przymusowy, zaś prawo karne materialne ma charakter subsydiarny względem innych dziedzin prawa, jednak w relacji z prawem karnym procesowym prawo materialne przyjmuje pozycję nadrzędną. Prawo karne procesowe, jako ustanowiony wzorzec procesu karnego, musi być dostosowane do potrzeb prawa karnego materialnego, które określa czyny przestępne, ustala zasady odpowiedzialności za nie, stosowanie kar i środków karnych wobec ich sprawców. Nie oznacza to, że w Kodeksie postępowania karnego nie mogą zostać zamieszczone przepisy o charakterze materialnym, takie rozwiązanie przewidywał chociażby art. $343 \$ 2$ pkt 1 i 2 k.p.k. w brzmieniu obowiązującym do 1 lipca 2015 r. (przepis upoważniał do nadzwyczajnego złagodzenia kary lub warunkowego zawieszenia jej wykonania), to jednak prawo karne procesowe pełni rolę służebną w stosunku do prawa karnego materialnego. Proces karny jest jedyną drogą, na której może być realizowane zagrożenie karą, związane $\mathrm{z}$ naruszeniem normy prawnomaterialnej ${ }^{42}$. Nie można więc zaakceptować sytuacji, w której prawo procesowe „modyfikuje” prawo materialne $\mathrm{w}$ zakresie przestępności czynu, wprowadzając niezależne, nieznane prawu materialnemu okoliczności wyłączające odpowiedzialność karną za popełniony czyn, w czasie gdy rola ta została zastrzeżona dla norm materialnokarnych, a rozwiązanie takie nie ma wyraźnej, jednoznacznej podstawy prawnej. Uzasadnienia dla koncepcji kontratypu poszukuje się w normach konstytucyjnych, ustawowych, chcąc przy ich łącznym stosowaniu „przeforsować” słuszność prezentowanego poglądu, który nie znajduje bezpośredniego prawnego umocowania.

Za istotę wszystkich kontratypów, co miało pozwolić na określenie wspólnego dla nich miernika, uważano konflikt dóbr prawem chronionych, którego rozwiązanie wymaga społecznie opłacalnego naruszenia jednego z nich ${ }^{43}$. Podstawę działania kontratypów miała stanowić zasada „większej korzyści niż straty” bądź „pierwszeństwa poszanowania niezaprzeczalnej wartości dobra prawnego przed nagannym jego naruszeniem”. Dla A. Zolla okoliczności kontratypowe uzasadniają naruszenie bądź zagrożenie dobra chronionego prawem, przy braku możliwości równoległej ochrony obu dóbr. Takie stanowisko podyktowane jest prezentowanym

Fatszywe zeznania a prawo do obrony, Glosa do uchwaty SN z dnia 20 września 2007 r., I KZP 26/07. MP 2008, z. 15, s. 837.

${ }^{42}$ K. Marszae, S. Stachowiak, K. Zgryzek. W: Proces karny. Red. K. Marszae. Katowice 2005 , s. 40.

${ }^{43}$ Idea konfliktu dwóch dóbr prawem chronionych, rozstrzyganego przy użyciu kontratypu, narodziła się w nauce niemieckiej. Jej przedstawicielami byli zwolennicy tzw. koncepcji monoteistycznych: W. Sauer, P. Noll - na ten temat zob.: T. KaczMareK: O tzw. okolicznościach..., s. 5. 
przez autora poglądem, że wystąpienie kontratypu nie prowadzi jednocześnie do zmiany wartości danego dobra prawnego, tym samym dobro, którego zniszczenie usprawiedliwiamy, nie przestaje być dobrem chronionym prawem ${ }^{44}$. Powracając do omawianego zagadnienia, wykreowany pozaustawowy kontratyp działania w zakresie uprawnień miał służyć wyeliminowaniu konfliktu, do jakiego dochodzi pomiędzy prawem do obrony a dobrem wymiaru sprawiedliwości, a więc dwoma dobrami prawnie chronionymi, w czasie gdy sprawca, zajmując status świadka, składa fałszywe zeznania co do okoliczności dotyczących jego prawa do obrony ${ }^{45}$. Powstały konflikt pomiędzy sprzecznymi interesami jednostki i ogółu może zostać rozstrzygnięty z pominięciem kontratypu, przy zastosowaniu art. 31 ust. 3 Konstytucji RP i wynikającej z niej zasady proporcjonalności. Takie zasadnicze uprawnienie jak wolność od samooskarżenia czy prawo do milczenia nie może zostać ograniczone z uwagi na dobro wymiaru sprawiedliwości. Kolizja dóbr może więc zostać rozstrzygnięta przy zastosowaniu innej metody - konstytucyjnej, bez konieczności tworzenia na potrzeby konkretnej sytuacji konstrukcji pozaustawowego kontratypu, co oczywiście wiązać by się musiało z przyjęciem określonych rozwiązań ustawowych.

$\mathrm{Na}$ marginesie zauważyć należy, że zaakceptowanie w całej rozciągłości stanowiska Sądu Najwyższego prowadzić winno do nieuchronnego, a jednocześnie logicznego wniosku, iż granice przedmiotowe kontratypu działania w zakresie prawa do obrony obejmować również powinny inne postępowania prowadzone na podstawie ustawy (cywilne, podatkowe, administracyjne). Rozstrzygnięcie zaś takie budzić będzie, co oczywiste, poważne wątpliwości. Do takiej konkluzji prowadziłaby natomiast konieczność zapewnienia spójnego systemu prawa, jak i orzecznictwa. Wprawdzie w powyższym zakresie Sąd Najwyższy nie udzielił jednoznacznej odpowiedzi i być może z uwagi na aktualną treść art. 233 k.k. nigdy tego nie uczyni, ale biorąc pod uwagę, że był to istotny, nierozstrzygnięty dotychczas problem, nie można byłoby wykluczyć, że i takie zagadnienie stałoby się przedmiotem badania Sądu Najwyższego. Nie ulega wątpliwości, że przesłuchanie rzeczywistego sprawcy przestępstwa co do przebiegu zdarzenia, nawet gdy

${ }^{44}$ A. Zoll: W sprawie kontratypów. PiP 2009, nr 4, s. 112.

${ }^{45}$ E. Plebanek stwierdziła, że: „pomimo krytycznych uwag pod adresem kontratypów pozaustawowych nie można całkowicie odmówić im racji bytu w obecnym porządku prawnym. Istnienie kontratypów pozaustawowych jest zasadne, gdy ustawodawca nie przewidział w postaci ustawowego kontratypu kolizji dóbr, która miała miejsce w rzeczywistości. Sąd powinien w takim przypadku ocenić tę kolizję tak, jakby była ona ustawowo opisanym kontratypem, tj. w oparciu o dyrektywy zasady proporcjonalności. Należy pamiętać jednak, że nadużywanie tego rodzaju możliwości może naruszać ustawowo gwarantowaną ochronę danego dobra poprzez decyzję pozbawioną podstawy ustawowej, a opartą jedynie na ogólnie sformułowanych normach konstytucyjnych" - E. PlebaneK: Materialne określenie przestępstwa. Warszawa 2009 r., LEX Prestige. 
doszło do tego jeszcze przed wszczęciem postępowania karnego w sprawie, będzie miało znaczenie dla realizacji jego prawa do obrony. Wydaje się, że groźba czy też obawa przed ewentualnymi konsekwencjami karnoprawnymi w przypadku odmowy odpowiedzi na pytanie byłaby znacznie mniejsza w sytuacji, gdy do przesłuchania doszłoby w toku postępowania innego niż karne. Pokusić można się o postawienie tezy, że ilekroć świadek lub strona postępowania składająca zeznania $\mathrm{w}$ innym postępowaniu prowadzonym na podstawie ustawy zostali pouczeni o możliwości odmowy odpowiedzi na pytanie, jeżeli zeznanie mogłoby narazić ich na odpowiedzialność karną, winni z prawa tego skorzystać. Ilekroć takie pouczenie nie nastąpi, świadek mógłby mówić nieprawdę bądź zatajać prawdę, zaś karalność za ten czyn zostałaby wyłączona na podstawie klauzuli niekaralności z art. 233 §3 k.k. Nie można jednak wykluczyć bezwzględnie, że również obrona świadka składającego fałszywe zeznania w toku innego procesu (niekarnego), a pouczonego o uprawnieniu odmowy odpowiedzi na pytanie, oparta na kontratypie działania w zakresie prawa do obrony w ocenie Sądu Najwyższego zajmującego się takim zagadnieniem mogłaby okazać się skuteczną ${ }^{46}$.

Omawiając koncepcję kontratypu prawa do obrony jako okoliczności wyłączającej bezprawność czynu składania fałszywych zeznań, nie można również nie zasygnalizować innej istotnej okoliczności. Zasada prawa karnego nullum crimen, nulla poena sine lege zakazuje prawa opartego na orzeczeniach sądowych lub rozstrzygnięciach doktryny, kierując się założeniem, że prawo karne musi być prawem pisanym i zawartym w ustawie $^{47}$. W nauce prawa karnego przyjmuje się na ogół, że zastosowanie kontratypów pozaustawowych, zwyczajowych czy też sformułowanych w doktrynie bądź orzecznictwie jest dozwolone, bowiem zawsze działają one na korzyść sprawcy i dlatego, ze względu na kierunek działania kontratypów, zasada nullum crimen sine lege nie znajduje zastosowania ${ }^{48}$. Pomimo jednak, że postulaty zasady nullum crimen sine lege nie odnoszą się - same w sobie - do rozwiązań działających na korzyść oskarżonego, w tym do kontratypów, to jednak, jak pisze słusznie Z. Jędrzejewski, „każ-

46 Zgodnie z treścią wyroku SA we Wrocławiu z dnia 26 października 2006 r.: „Oskarżony może bronić się wszelkimi prawnie niezakazanymi metodami i sposobami, wykorzystując w tym celu znane mu fakty (ich treściowe przedstawienie lub ukrycie, a nawet zafałszowanie), jak też przepisy prawa, w tym poprzez ich interpretację dla siebie korzystną, i w tym zakresie chronią go dyrektywy zasad prawa do obrony oraz nemo se ipsum accusare tenetur", a wiemy, że druga ze wskazanych zasad obowiązuje już od momentu popełnienia czynu, chroniąc również świadka - wyrok SA we Wrocławiu z dnia 26 października 2006 r., II AKa 289/06, LEX nr 203385.

${ }^{47}$ M. SAFIAN, L. BoseK: Konstytucja RP. T. I: Komentarz do art. 1-86...

${ }^{48} \mathrm{H}$. RaJzMAN: Analogia in bonam partem i zasada legalizmu $w$ prawie karnym. AUMCS 1966, vol. XIII, no. 2, Sectio G, s. 43; W. Wolter: Funkcja btędu w prawie karnym. Warszawa 1965, s. 134. 
de takie ograniczenie karalności niewątpliwie nadwyręża ochronę dobra dotkniętego naruszeniem, a każda taka legalizacja zachowania sprawcy w sytuacji konfliktowej prowadzi do uznania zachowania strony przeciwnej za bezprawne, w konsekwencji często również za przestępne ${ }^{49}$.

Sąd Najwyższy, „tworząc” niejako kontratyp działania w zakresie prawa do obrony, wszedł w kompetencje władzy ustawodawczej, przejmując atrybut prawodawcy ${ }^{50}$. W dalszym ciągu mamy do czynienia z kontratypem pozaustawowym. Taki rodzaj kontratypu A. Zoll uznał za sprzeczny z konstytucyjną zasadą podziału władzy, bowiem kreowany on jest z wyłączeniem ustawodawcy. H. Rajzman, nawiązując do wypowiedzi W. Sauera, że formułowanie pewnych kontratypów pozostawia się nauce, stwierdził, że w tezie tej brak jest określenia kto i gdzie przekazał nauce uprawnienia do „kontratypizowania”51. Tworzenie pozaustawowych okoliczności wyłączających odpowiedzialność karną narusza zasadę podziału władzy oraz ochrony osoby pokrzywdzonej. „Sądy, podobnie jak inne organy władzy publicznej, działają na podstawie i w granicach prawa (art. 7 Konstytucji). Z zasady tej, należącej do kanonu zasad państwa prawnego, wynikają określone konsekwencje. W szczególności: organowi przysługują tylko kompetencje przyznane przez prawo, organ działa tylko w formach przewidzianych przez prawo, działania organu wywołuja tylko skutki przewidziane przez prawo. Do podstawowych założeń polskiego ustroju konstytucyjnego należy zasada podziału i równości władzy ustawodawczej, wykonawczej i sądowniczej (art. 10 Konstytucji). Obowiązywanie tej zasady nie wyklucza wkraczania jednej z władz w dziedzinę należącą do innej władzy, ale tylko w sytuacji ściśle określonej w przepisach konstytucyjnych" 52 . W Konstytucji RP brak zaś jest prawotwórczego upoważnienia dla władzy sądowniczej.

Ostatecznie zasygnalizować należy znaczenie moralne, wydźwięk etyczny nowo powstałego kontratypu. Podejmując pierwszą uchwałę z dnia 20 czerwca 1991 r., Sąd Najwyższy wyznaczył pewien kierunek

${ }^{49}$ Z. JĘDRZEJewski: Nullum crimen sine lege i kontratypy..., s. 7-9.

${ }^{50}$ Problem ten zauważył A. Wąsek, stwierdzając, iż „rezultat jest taki, że w ten sposób następuje poprawienie tekstu prawnego, do czego podmiot stosujący wykładnię zazwyczaj nie jest uprawniony" - A. WĄSEK: Glosa do uchwaty..., s. 75; E. Plebanek opowiedziała się przeciwko przyznawaniu sądom władzy decydowania czy dana norma ustanowiona przez ustawodawcę nie będzie obowiązywać z uwagi na zastosowanie kontratypu pozaustawowego. Jest to rozwiązanie niedopuszczalne z punktu widzenia zasady podziału władzy - E. Plebanek: Materialne określenie..., LEX Prestige. Problem ten zdawał się zauważać już C. Beccaria, pisząc: „Prawo wykładni ustawy karnej nie może przysługiwać sędziom kryminalnym już choćby dlatego, że nie są oni prawodawcami" - C. BeCCARIA: O Przestępstwach i karach. Warszawa 1959, s. 63.

${ }^{51}$ Z. JęDRZEJEWski: Nullum crimen sine lege i kontratypy..., s. 9.

${ }^{52}$ A. MączYŃski: Bezpośrednie stosowanie Konstytucji..., s. 5. 
dalszego orzecznictwa, które było naturalną konsekwencją pierwotnie wyrażonego stanowiska, a które skutkowało poszerzeniem zakresu zachowań wyłączonych spod dyspozycji art. $233 \S 1$ k.k. Ponadto orzecznictwa Sądu Najwyższego nie można traktować jako przypadku czy przejściowej zmiany poglądu, skoro zostało ono wielokrotnie potwierdzone kolejnymi wyrokami ${ }^{53}$. Intencje Sądu Najwyższego były jak najbardziej słuszne i uzasadnione okolicznościami. Celem zajętego stanowiska było wyeliminowanie naruszeń polegających na zamierzonym opóźnianiu wydawania postanowienia o przedstawieniu zarzutów wobec osób faktycznie podejrzanych o popełnienie przestępstwa po to, aby można je było przesłuchać $\mathrm{w}$ charakterze świadków pod groźbą odpowiedzialności karnej za składanie fałszywych zeznań, względnie zamierzonego przesłuchania sprawcy $\mathrm{w}$ innym postępowaniu karnym w charakterze świadka w czasie, gdy okoliczności jednoznacznie wskazywały na jego udział w przestępstwie. Stanowisko Sądu Najwyższego doprowadziło jednak do przewrotnych konsekwencji, sprzecznych jak się wydaje z zasadniczym celem orzecznictwa. W pełni należy podzielić pogląd M. Burdy wyrażony w toku II Krakowskiego Forum Karnistycznego w 2012 r. w Krakowie, iż zajmując takie stanowisko Sąd Najwyższy nakręcił „,spiralę zbrodni”, doprowadzając do sytuacji, w której sprawca przesłuchiwany w charakterze świadka może skutecznie i bezkarnie składać fałszywe zeznania, tworząc tym samym bardzo skuteczną formę obrony na przedpolu procesu karnego. Aktualne wówczas może stać się stwierdzenie, że „prawo chroni przestępcę", dając mu dodatkowe uprawnienie, służące uniknięciu odpowiedzialności karnej. Negatywny staje się również wydźwięk społeczny proponowanego kontratypu. Trudno jest zaakceptować, szczególnie pokrzywdzonym, sytuację, $\mathrm{w}$ której sprawca przestępstwa poza możliwością ukrywania prawdy w toku całego procesu może również kłamać wcześniej, nim stanie się stroną, utrudniając tym samym ustalenie prawdy materialnej, na której przecież społeczeństwu najbardziej zależy, nie ponosząc z tego tytułu żadnej odpowiedzialności. Kontratyp może stać się źródłem nadużyć, nie można bowiem wykluczyć sytuacji, w której zachowanie osoby podejrzanej polegające na złożeniu fałszywych zeznań spo-

${ }^{53}$ Wyrok SN z dnia 4 lipca 2000 r., WKN 12/00, LEX nr 438511; postanowienie SN z dnia 22 września 2008 r., IV KK 241/08, LEX nr 464981; wyrok SN z dnia 30 czerwca 2009 r., V KK 25/09, LEX nr 512071. Nie ulega wątpliwości, że udzielona przez Sąd Najwyższy odpowiedź na zagadnienie prawne, wymagające zasadniczej wykładni ustawy, wiąże wyłącznie konkretny sąd w danej sprawie, to jednak dla innych sądów jest wyraźną wskazówką. Przełamanie przez sąd niższego rzędu zapatrywania Sądu Najwyższego na tożsame zagadnienie może spotkać się ze znaczną dezaprobatą. Skoro bowiem pogląd Sądu Najwyższego jest w konkretnej sprawie ustalony, to w podobnych sprawach rozstrzygnięcia powinny być identyczne. 
woduje, w sposób zamierzony czy też nie, skierowanie podejrzeń wobec innych osób, faktycznie niewinnych i pociągnięcie ich do odpowiedzialności karnej za cudzy czyn. Kontratyp może zostać wykorzystany w innym postępowaniu, np. cywilnym, gdzie strona postępowania-sprawca przestępstwa składa fałszywe zeznania istotne dla jego odpowiedzialności karnej, ale pozwalające mu zarazem na uzyskanie pozytywnego rezultatu $\mathrm{w}$ tym postępowaniu. Wprowadzając dodatkowe uprawnienia przysługujące sprawcy, doprowadzono do powstania kolejnych przeszkód utrudniających i wydłużających dotarcie do prawdy.

Problem przymusowego „położenia” sprawcy przestępstwa, który przesłuchany w charakterze świadka byłby zmuszony dostarczać informacji na swoją niekorzyść, stał się przy okazji omawiania koncepcji kontratypu działania w zakresie prawa do obrony przedmiotem szerokiej dyskusji w środowisku naukowym. Podejmowane rozważania doprowadziły do alternatywnych koncepcji dotyczących wyłączenia odpowiedzialności karnej za składanie fałszywych zeznań przez rzeczywistego sprawcę przestępstwa: obrona konieczna ${ }^{54}$, stan wyższej konieczności ${ }^{55}$, błąd co do znamion przestępstwa z art. $233 \S 1$ k.k. ${ }^{56}$, brak karygodności czynu ${ }^{57}$, zeznania $\mathrm{w}$ aspekcie materialnym ${ }^{58}$. Różnorodność koncepcji świadczy o znaczeniu i powadze omawianego zagadnienia oraz dostrzeganiu przez wielu problemu przymusowego „położenia” rzeczywistego sprawcy przestępstwa przesłuchiwanego w charakterze świadka co do okoliczności mających znaczenie dla jego odpowiedzialności karnej.

Rozwiązania można byłoby również poszukiwać w materialnoprawnym ujęciu reguły nemo se ipsum accusare tenetur. W zakresie prawa karnego materialnego reguła ta wyraża się w ten sposób, iż wyłącza odpowiedzialność karną sprawcy przestępstwa za brak aktywności z jego strony, polegający na braku współdziałania z organami państwa w gromadzeniu materiału dowodowego przeciwko sobie, w tym również prawdziwych, szczerych zeznań lub innych oświadczeń niezależnie od roli procesowej, $\mathrm{w}$ jakiej sprawca przestępstwa występuje w procesie karnym. Przykład takiego rozwiązania znajdziemy w treści art. 236 \$2 k.k., który stanowi, iż nie podlega karze, kto zataja dowody niewinności z obawy przed odpowiedzialnością karną grożącą jemu samemu lub jego najbliższym lub

${ }^{54}$ W. CIEŚLAK: Brak lojalności organu procesowego jako okoliczność wyłączająca odpowiedzialność karna za złożenie fałszywych zeznań. W: Reforma prawa karnego propozycje i komentarze. Ksiega pamiatkowa Profesor Barbary Kunickiej-Michalskiej. Red. J. JaKUBOwsKA-Hara, C. NowaK, J. Skupiński. Warszawa 2008, s. 334-336.

${ }^{55}$ A. LACH: Glosa do uchwaty..., LEX Prestige.

${ }^{56}$ D. Gruszecka: Zasiegg prawa do obrony..., s. 139.

57 J. Potulski: Glosa do uchwały..., s. 116.

${ }^{58}$ M. BIELSKI: Wytączenie przestępności..., s. 1. 
$\mathrm{w}$ art. $240 \S 3$ k.k., zgodnie z którym nie podlega karze, kto zaniechał zawiadomienia z obawy przed odpowiedzialnością karną grożącą jemu samemu lub jego najbliższym.

W kontekście powyższego należałoby postulować, aby de lege ferenda klauzula niekaralności z art. 233 k.k. adresowana była do świadków-rzeczywistych sprawców przestępstwa. Z uwagi na fakt, iż art. 233 \$3 k.k. odnosi się również do sytuacji osoby nie posiadającej wiedzy o prawie odmowy złożenia zeznania (w związku z nieobowiązkowym pouczeniem świadka o prawie z art. $183 \S 1$ k.p.k.), postulować można, aby proponowana nowa klauzula niekaralności zredagowana została w kolejnej jednostce redakcyjnej jako art. 233 §3a k.k., stanowiąc uzupełnienie i dopełnienie poprzedniej klauzuli z art. 233 §3 k.k. Bez wątpienia dotychczasowa treść klauzuli niekaralności nie gwarantuje sprawcom przestępstwa właściwej, zgodnej z regułą nemo tenetur, ochrony. Proponowana klauzula niekaralności mogłaby brzmieć: „Nie podlega karze sprawca przestępstwa, który w obawie przed odpowiedzialnością karną grożącą jemu samemu za popełniony czyn, składa fałszywe zeznania dotyczące tego czynu".

Zagadnienie stało się ponownie przedmiotem dyskusji, gdy ustawą z dnia 11 marca 2016 r. o zmianie ustawy - Kodeks postępowania karnego oraz niektórych innych ustaw ${ }^{59}$ ustawodawca wprowadził do art. 233 k.k. nową jednostkę redakcyjną - $\$ 1$ a, ale o zupełnie innym brzmieniu aniżeli powyżej proponowana, tj. ,Jeżeli sprawca czynu określonego w $\$ 1$ zeznaje nieprawdę lub zataja prawdę z obawy przed odpowiedzialnością karną grożącą jemu samemu lub jego najbliższym, podlega karze pozbawienia wolności od 3 miesięcy do lat 5".

W uzasadnieniu rządowego projektu ustawy o zmianie ustawy Kodeks postępowania karnego oraz niektórych innych ustaw wskazano, iż: „Zmiana w zakresie art. 233 k.k. ma na celu zwiększenie stopnia ochrony wymiaru sprawiedliwości przed wprowadzaniem w błąd organów procesowych w wyniku składania fałszywych zeznań lub fałszywych opinii. Zeznania świadków i opinie biegłych są to podstawowe źródła dowodowe. Wprowadzenie w błąd organów wymiaru sprawiedliwości może zakończyć postępowanie wyrokiem oczywiście niesprawiedliwym, i to zarówno poprzez skazanie osoby niewinnej, jak i brak skazania osoby winnej" 60 . Zdaniem projektodawców Kodeks postępowania karnego przewiduje wystarczające gwarancje prawa do obrony przewidzianego $\mathrm{w}$ art. 6 EKPC i art. 42 ust. 2 Konstytucji RP, a realizacji gwarancji należy upatrywać w prawie do odmowy zeznań i prawie do odmowy odpowiedzi

\footnotetext{
${ }^{59}$ Dz.U. 2016, poz. 437.

${ }^{60} \mathrm{http}: / /$ www.sejm.gov.pl/sejm8.nsf/druk.xsp?nr=207 [dostęp: 16.09.2017].
} 
na pytanie, o którym mowa w art. 182 i art. 183 k.p.k. Skorelowane z tym uprawnieniem wyłączenie karalności osoby, która złożyła fałszywe zeznanie, nie wiedząc o możliwości skorzystania z uprawnień, przewidziane $\mathrm{w}$ art. $233 \S 3$ k.k., zapewnia dostateczną ochronę. Jako argument przemawiający za koniecznością zmiany powołano się na systemy prawne innych państw, które ratyfikowały Europejską Konwencję Praw Człowieka, jak Niemcy, Szwajcaria, Włochy, Wielka Brytania, przybliżając jednak jako przykład wyłącznie regulację prawa niemieckiego.

Podsumowując, wskazano, iż w związku z pojawiającymi się w judykaturze wypowiedziami utożsamiającymi prawo do obrony z prawem do wprowadzenia w błąd organów procesowych w zakresie wykraczającym poza stosowanie instytucji procesowych celem „rozstrzygnięcia tego rodzaju wątpliwości i interpretacji mających negatywne konsekwencje dla pewności prawnej i skuteczności wymiaru sprawiedliwości projektodawca zdecydował się jednoznacznie uznać zachowanie uczestnika postępowania, polegające na świadomym składaniu fałszywych zeznań i wprowadzania w błąd organu procesowego pomimo pouczenia go o prawie do odmowy składania zeznań lub odpowiedzi na pytania, za czyn zabroniony jako przestępstwo. Znalazło to wyraźne odzwierciedlenie normatywne w postaci zamieszczenia odrębnego przepisu art. 233 §1a k.k., przewidującego odpowiedzialność karną w takich wypadkach".

Wskazać należy, iż omawiana zmiana nie była jedyną, jaka nastąpiła w ramach art. 233 k.k., bowiem tą samą nowelizacją zaostrzeniu uległa sankcja karna za czym opisany w dyspozycji art. 233 § 1 k.k. (od 6 miesięcy do lat 8) oraz zmieniono treść $\$ 3$, nadając mu następujące brzmienie: „Nie podlega karze za czyn określony w $§ 1$ a, kto składa fałszywe zeznanie, nie wiedząc o prawie odmowy zeznania lub odpowiedzi na pytania". Wszystkie omawiane zmiany miały zwiększyć skuteczność wymiaru sprawiedliwości w zakresie dążenia do prawdy materialnej.

Do rządowego projektu ustawy o zmianie ustawy - Kodeks postępowania karnego oraz niektórych innych ustaw (Druk Sejmowy nr 207) prawo złożenia opinii miała Krajowa Rada Prokuratury ${ }^{61}$, Prokurator Generalny ${ }^{62}$, Krajowa Rada Sądownictwa ${ }^{63}$, Krajowa Rada Radców Prawnych ${ }^{64}$, Sąd Najwyższy. Krajowa Rada Prokuratury nie przedłożyła żadnej opinii, uza-

\footnotetext{
${ }^{61}$ http://orka.sejm.gov.pl/Druki8ka.nsf/0/8A270DCCB24D2E31C1257F5E004905B5/ \%24File/207-003.pdf [dostęp: 16.09.2017].

${ }^{62}$ http://orka.sejm.gov.pl/Druki8ka.nsf/0/4057EAF4004A8D08C1257F64005BEDCB/ \%24File/207-004.pdf [dostęp: 16.09.2017].

${ }^{63} \mathrm{http}$ ://orka.sejm.gov.pl/Druki8ka.nsf/0/E4E18B486CF6499CC1257F5B0035420F/ \%24File/207-002.pdf [dostęp: 16.09.2017].

${ }^{64} \mathrm{http}: / /$ orka.sejm.gov.pl/Druki8ka.nsf/0/0F886B16326355A1C1257F5400517C71/\% 24File/207-001.pdf [dostęp: 16.09.2017].
} 
sadniając ten fakt obszernością projektu aktu prawnego oraz rozpoczęciem prac legislacyjnych w okresie poprzedzającym posiedzenie Rady. Krajowa Rada Sądownictwa oraz Ośrodek Badań, Studiów i Legislacji Krajowej Rady Radców Prawnych w swoich opiniach nie ustosunkowali się do treści nowelizowanego art. 233 k.k. Stanowisko w tej sprawie zajął wyłącznie Prokurator Generalny oraz Pierwsza Prezes Sądu Najwyższego.

Prokurator Generalny ${ }^{65}$ odnosząc się do propozycji nowelizacji art. 233 k.k., podniósł: „Nie kwestionując kryminalnopolitycznej zasadności tego rozwiązania (odpowiedzialność karna tego, kto składa fałszywe zeznania mające służyć za dowód z obawy przed odpowiedzialnością karną), należy zauważyć, iż przewidzianemu w projekcie istotnemu zaostrzeniu ustawowego zagrożenia za występek z art. 233 § 1 k.k. powinno towarzyszyć wprowadzenie uprzywilejowanego typu tego przestępstwa, który powinien stanowić czyn zabroniony o znamionach opisanych w proj. art. 233 §la k.k. Bez wątpienia sprawca, który składa fałszywe zeznania z obawy przed odpowiedzialnością karną grożącą jemu samemu lub jego najbliższym, ze względu na pobudki, które nim kierują, powinien być znacznie łagodniej traktowany niż świadek, który dopuszcza się fałszywych zeznań przykładowo motywowany uczuciem zemsty albo dla osiągnięcia korzyści majątkowej lub osobistej. Uzasadnione również byłoby wprowadzenie możliwości zastosowania wobec sprawcy przestępstwa określonego w proj. art. 233 § la k.k. nadzwyczajnego złagodzenia kary, co wymaga dokonania stosownego uzupełnienia normatywnych podstaw tej instytucji określonych w art. 233 § k.k”. Opinia Prokuratora Generalnego została wydana w dniu 23 lutego 2016 r., a więc jeszcze przed połączeniem funkcji Ministra Sprawiedliwości i Prokuratora Generalnego.

Nie opowiadając się za zasadnością wprowadzonego rozwiązania, nie sposób odmówić słuszności stanowisku Prokuratora Generalnego w zakresie, w jakim opowiada się za wprowadzeniem uprzywilejowanego typu przestępstwa. Analiza systemów prawnych, na które powołał się projektodawca, wskazuje, iż w prawie niemieckim złożenie fałszywych zeznań z obawy przed grożącym niebezpieczeństwem postawienia zarzutów stanowi przestępstwo, a sąd może co najwyżej złagodzić karę lub odstąpić od jej wymierzenia, obawa taka nie powoduje wyłączenia bezprawności czynu polegającego na złożeniu fałszywych zeznań. Podobnie zagadnienie zostało uregulowane $\mathrm{w}$ prawie szwajcarskim i włoskim, $\mathrm{z}$ ta różnicą, iż sąd może nadzwyczajnie złagodzić karę, jednakże wina i bezprawność nie zostają wyłączone $^{66}$. Zupełnie niezrozumiałe jest powoływanie się przez

${ }^{65} \mathrm{http}$ ://orka.sejm.gov.pl/Druki8ka.nsf/0/4057EAF4004A8D08C1257F64005BEDCB/ \%24File/207-004.pdf [dostęp: 16.09.2017].

${ }^{66}$ J. Czabański, M. WarchoŁ: Prawo do milczenia czy prawo do kłamstwa. Prok. i Pr. 2007, nr 12, s. 41-43. 
projektodawcę na regulację anglosaską, skoro w prawie Wielkiej Brytanii prawo do milczenia i obowiązek mówienia prawdy znajduje zastosowanie zarówno co do zeznań, jak i wyjaśnień, zaś z prawa do milczenia można wyprowadzić nawet negatywne wnioski, jeżeli odmowa odpowiedzi na pytanie nastąpi bez „dobrej” przyczyny, a także, gdy oskarżony powołuje się na okoliczności, na które mógł się powołać wcześniej ${ }^{67}$.

Pierwsza Prezes Sądu Najwyższego ${ }^{68}$, wyrażając stanowisko Sądu Najwyższego, podkreśliła, że: „[...] w ramach prawa do obrony zawiera się brak konieczności dostarczania dowodów na swoją niekorzyść. Obecna regulacja, znajdująca szerokie poparcie w orzecznictwie Sądu Najwyższego, wiąże się z założeniem, że prawo to realizuje się nie tylko w momencie składania wyjaśnień, ale także w sytuacji składania zeznań. Nieżyciowy jest wymóg, aby sprawca składając zeznania w sprawie dotyczącej swojego czynu, jak również w sprawie dotyczącej czynu innej osoby, był obowiązany do podawania informacji, które wskazywałyby na popełnione przez niego przestępstwa. W praktyce bardzo istotną informacją dla organów procesowych będzie skorzystanie przez osobę składającą zeznania z prawa do odmowy ich składania, jak również do odmowy odpowiedzi na zadane pytanie".

Pierwsza Prezes Sądu Najwyższego podkreśliła kwestię nierozważenia przez projektodawcę, jakie jest źródło kontratypu wyłączającego bezprawność $\mathrm{w}$ razie składania fałszywych zeznań przez sprawcę czynu zabronionego. Ponownie podkreśliła za Sądem Najwyższym, iż: „Ten nie wywodzi się z art. 6 k.p.k., a z art. 42 ust. 2 Konstytucji RP. W tym zakresie należy odesłać do bogatego orzecznictwa Sądu Najwyższego (zob. np. uchwała SN z dnia 20 dnia września 2007 r., 1 KZP 26/07, OSNKW 2007, z. 10, poz. 71; wyrok SN z dnia 17 października 2012 r., IV KK 99/12; postanowienie SN z dnia 22 września 2008 r., IV KK 241/08; wyrok SN z dnia 30 czerwca 2009 r., V KK 25/09; wyrok SN z dnia 22 listopada 2012 r., V KK 265/12)". Zadała pytanie, czy nowelizacja art. 233 k.k. przez dodanie $\$ 1$ a zmieni standard konstytucyjnego prawa do obrony. Zgodnie bowiem z obowiązującymi regułami wykładni Konstytucji nie interpretuje się w perspektywie ustaw. Wręcz odwrotnie, to ustawy interpretuje się w aspekcie konstytucyjnym. Podkreśliła, iż wobec powyższego powstaje uzasadniona wątpliwość, czy projektowany art. $233 \S 1$ a k.k. nie pozostaje w kolizji z art. 42 ust. 2 Konstytucji RP, jednocześnie dając asumpt do twierdzenia, że wobec kontratypu w ustawie zasadniczej art. 233 § 1a k.k. będzie dysfunkcyjny.

${ }^{67}$ Ibidem, s. 40.

${ }^{68} \mathrm{http}: / /$ orka.sejm.gov.pl/Druki8ka.nsf/0/CC7AB6DB0551BFC0C1257F6B003FCB99 /\%24File/207-005.pdf [dostęp: 16.09.2017]. 
W kontekście ostatniego argumentu Pierwszej Prezes Sądu Najwyższego przypomnieć jednak należy, iż zgodnie z utrwaloną linią orzecznictwa, zarówno Trybunału Konstytucyjnego, jak i Sądu Najwyższego, sądy i inne organy stosowania prawa nie mają kompetencji do orzekania o niekonstytucyjności przepisu ustawy i odmowy jego stosowania. Domniemanie zgodności ustawy z Konstytucją może być obalone jedynie wyrokiem Trybunału Konstytucyjnego, a związanie sędziego ustawą, o którym mowa w art. 178 ust. 1 Konstytucji RP, obowiązuje dopóty, dopóki ustawie tej przysługuje moc obowiązująca. Brak w Konstytucji przepisu, który przyznawałby sądom i innym organom powołanym do stosowania prawa kompetencje do kontroli konstytucyjności aktów ustawowych (na użytek rozpoznawanej sprawy) nie pozwala - ze względu na wyrażoną w art. 7 Konstytucji zasadę działania organów władzy publicznej na podstawie i w granicach prawa - domniemywać tej kompetencji. Jeżeli sąd jest przekonany o niezgodności przepisu z Konstytucją lub ma w tym względzie wątpliwości, powinien zwrócić się do Trybunału Konstytucyjnego z pytaniem prawnym na podstawie art. 193 Konstytucji RP ${ }^{69}$. Orzeczenie Trybunału, jak stanowi art. 190 ust. 1 Konstytucji, rozstrzygające pytanie prawne ma charakter powszechnie obowiązujący, zatem każdy inny sąd rozpoznając podobną sprawę, powinien odmówić zastosowania przepisu niezgodnego z Konstytucją.

Sąd Najwyższy podkreślił nadto, iż: „Do odmiennych wniosków nie prowadzi aprobowana w orzecznictwie dyrektywa wykładni w zgodzie z Konstytucją, sprzeciwiająca się przyjmowaniu takich możliwości interpretacji przepisu ustawy, które prowadziłyby do jego niezgodności z Konstytucją, jeżeli możliwe jest również takie rozumienie interpretowanego przepisu, że jest on z nią zgodny. Dyrektywa ta ma zastosowanie w sytuacji, w której przepis ustawy budzi wątpliwości i konieczna jest jego wykładnia, a zastosowanie podstawowych dyrektyw interpretacyjnych prowadzi do różnych wyników. W takiej sytuacji dyrektywa wykładni w zgodzie z Konstytucją przemawia za przyjęciem tego z możliwych sposobów interpretacji przepisu ustawy, który nie prowadzi do jego niezgodności z Konstytucją. Dyrektywa wykładni w zgodzie z Konstytucją nie może jednak prowadzić do wykładni wykraczającej poza granice możli-

${ }^{69}$ Wyrok TK z dnia 31 stycznia 2001 r., P 4/99, OTK 2001, nr 1, poz. 5; wyrok TK z dnia 4 grudnia 2001 r., SK 18/00, OTK 2001, nr 8, poz. 256; wyrok SN z dnia 30 października 2002 r., V CKN 1456/00, LEX nr 57237; wyrok SN z dnia 27 marca 2003 r., V CKN 1811/00, LEX nr 521816; wyrok SN z dnia 6 listopada 2003 r., II CK 184/02, LEX nr 1129611; wyrok SN z dnia 16 kwietnia 2004 r., I CK 291/03, OSNC 2005, nr 4, poz. 71; wyrok SN z dnia 24 czerwca 2004 r., III CK 536/02, LEX nr 172784; wyrok SN z dnia 3 grudnia 2008 r., V CSK 310/08, LEX nr 484695. 
wego znaczenia interpretowanego tekstu, byłoby to bowiem równoznaczne z kontrolą zgodności stosowanego przepisu z Konstytucją"70.

Na skutek nowelizacji art. 233 k.k. straciła na aktualności teza wyrażona w uchwale Sądu Najwyższego z dnia 20 września 2007 r., iż „nie popełnia przestępstwa fałszywych zeznań (art. 233 \$1 k.k.), kto umyślnie składa nieprawdziwe zeznania dotyczące okoliczności mających znaczenie dla realizacji jego prawa do obrony (art. 6 k.p.k.)" "71. Podobnie stanie się z tezami wyrażonymi przez Sąd Najwyższy w uchwale z dnia 20 czerwca 1991 r. i 26 kwietnia 2007 r. Co prawda w uchwale z 2007 r. mocno sygnalizowany był problem odebrania zeznań od osoby faktycznie podejrzanej i zwłoki organów ścigania w wydaniu postanowienia o przedstawieniu zarzutów z uwagi na względy taktyki prowadzącego postępowanie, a w konsekwencji naruszenie przez organ ścigania obowiązku wynikającego z art. 313 \$1 k.p.k., niemniej jednak i w tym przypadku Sąd Najwyższy jako podstawę wyłączenia bezprawności czynu wskazywał przepisy ustawy procesowej (art. $313 \S 1$ k.p.k. w zw. z art. $74 \S 1$ k.p.k. i art. 175 §1 k.p.k.), ujawniające aksjologiczną i zakresową zbieżność z treścią konstytucyjnej zasady prawa do obrony. W świetle aktualnego brzmienia art. $233 \S 1 \mathrm{a}$ k.k. osoba, która została przesłuchana w charakterze świadka w czasie, gdy podczas przesłuchania istniał stan, w którym dane zebrane $\mathrm{w}$ toku postępowania „uzasadniały dostatecznie podejrzenie", że popełniła czyn, a mimo to nie przedstawiono jej zarzutów (art. 313 §1 k.p.k.), poniesie odpowiedzialność karną za przestępstwo składania fałszywych zeznań. Może to oznaczać przyzwolenie do opóźnienia tej czynności, co stanowi oczywistą nieprawidłowość, pozbawiającą taką osobę prawa do obrony i wynikającego stąd prawa do odmowy złożenia wyjaśnień. Podobnie ustawodawca dopuszcza możliwość przesłuchania w charakterze świadka w jego własnej sprawie osoby, co do której faktyczne dane wskazują na uzasadnione podejrzenie popełnienia przestępstwa, jednak stopień podejrzenia jest niższy niż dostatecznie uzasadniony, pozostawiając tej osobie wyłącznie uprawnienie z art. 182 i 183 k.p.k.

W konsekwencji z dniem wejścia w życie ustawy z dnia 11 marca 2016 r., tj. od dnia 15 kwietnia 2016 r., świadek-rzeczywisty sprawca przestępstwa składając fałszywe zeznania co do okoliczności popełnionego przez niego czynu celem uniknięcia odpowiedzialności karnej, nie znajduje się w sytuacji kontratypowej, a za składanie fałszywych zeznań może zostać skuteczne pociągnięty do odpowiedzialności karnej.

${ }^{70}$ Wyrok SN z dnia 24 listopada 2015 r., II CSK 517/14, LEX nr 1940564.

${ }^{71}$ Kodeks karny. Komentarz aktualizowany. Red. M. Mozgawa. LEX Gamma; Kodeks karny. Komentarz. Red. V. KonarsKa-WrzoseK. LEX Gamma; Kodeks karny. Komentarz. Wyd. V. Red. M. FiLAR. LEX Gamma. 
„Wyjściem awaryjnym” dla sprawcy przestępstwa przesłuchiwanego $\mathrm{w}$ charakterze świadka pozostaje zatem wyłącznie regulacja z art. 183 $\S 1$ k.p.k., która oceniana jest jako uprawnienie privilegium odiosum ${ }^{72}$. Przedstawiciele doktryny powszechnie podkreślają, że świadek-sprawca postawiony w sytuacji konfliktowej prędzej skłamie, niż narazi się na jakiekolwiek podejrzenia ${ }^{73}$. Sąd Najwyższy w uchwale z dnia 26 kwietnia 2007 r. stwierdził, iż utrzymywanie, że uprawnienie określone w art. 183 $\S 1$ k.p.k. stwarza w takim wypadku szansę realizacji prawa do obrony i zasady nemo tenetur byłoby przejawem hipokryzji i lekceważenia instytucji procesowych ${ }^{74}$. Jako podsumowanie przywołać można stwierdzenie P. Sowińskiego, który pisze: „[...] wewnętrzna sprzeczność sprawia, że instytucja ta ma w gruncie rzeczy »minimalne znaczenie praktyczne«, sama zaś instytucja dotknięta jest wadą wrodzoną, której nie jest w stanie uleczyć żadna kuracja. Każdy kolejny wprowadzający ją przepis - o ile opierałby się na podobnym mechanizmie - miałby wyłącznie instrukcyjny charakter"75.

Aby móc mówić o potencjalnym, gwarancyjnym charakterze uprawnienia wynikającego z art. $183 \S 1$ k.p.k., należałoby w pierwszej kolejności uczynić owo pouczenie obligatoryjnym. Wówczas dawałoby pewność, iż zawsze następuje ono $\mathrm{w}$ odpowiednim momencie i to niezależnie od woli czy wiedzy organu prowadzącego przesłuchanie ${ }^{76}$. Zbędnym wydaje się być prawo, o którym osoba mogąca z niego skorzystać nie posiada wiedzy bądź dowiaduje się za późno. Pozbawiając świadka takiego pouczenia, honoruje się tych świadków, którzy mieli już kontakt z wymiarem sprawiedliwości i o takiej możliwości wiedzą z doświadczenia albo skorzystali uprzednio z pomocy profesjonalisty, uzyskując stosowną wiedzę. $\mathrm{W}$ ten

72 K. ŁoJewsKI: Instytucja odmowy zeznań $w$ polskim procesie karnym. Warszawa 1971, s. 130-131; „W przypadku art. 183 §1 k.p.k. droga »do raju « nieświadczenia zeznań na niekorzyść swoją lub swoich bliskich wiedzie przez »czyściec « przyznania się do winy lub obciążania najbliższych" - ibidem, s. 138 i 145.

${ }^{73} \mathrm{~A}$. Lach pisze nawet, iż gwarancja wynikająca z tego przepisu ma wysoce iluzoryczne znaczenie - A. LACH: Glosa do uchwały..., LEX Prestige; Sąd Najwyższy w uchwale z dnia 26 kwietnia 2007 r. stwierdził, iż utrzymywanie, że uprawnienie określone w art. 183 $\S 1$ k.p.k. stwarza w takim wypadku szansę realizacji prawa do obrony i zasady nemo tenetur byłoby przejawem hipokryzji i lekceważenia instytucji procesowych.

${ }^{74}$ I KZP 4/07, LEX nr 244459.

${ }^{75}$ P.K. Sowiński: Prawo świadka do odmowy zeznań w procesie karnym. Warszawa 2004, s. 126.

${ }^{76}$ Prokurator Prokuratury Apelacyjnej Janusz Śliwa w toku II Krakowskiego Kongresu Karnistycznego w 2012 r. w Krakowie wyraził pogląd, iż treść art. 183 k.p.k. powinna stać się przedmiotem wiedzy powszechnej, podobnie jak w państwach common low formuła: „masz prawo zachować milczenie, wszystko, co powiesz, może zostać użyte przeciwko tobie", tym bardziej, że o obawie przed odpowiedzialnością karną w rozumieniu art. 183 k.p.k. decyduje przekonanie świadka, nie zaś samego organu. 
sposób dochodzi do zwyczajnego różnicowania świadków pod względem znajomości ich praw. Nie można jednak wykluczyć, iż z czasem instytucja odmowy odpowiedzi na pytanie będzie wykorzystywana nie w celu, jakiemu miała pierwotnie służyć. Biorąc pod uwagę, iż świadek nie ma obowiązku podawania motywów odmowy odpowiedzi na pytanie, a zatem wystarczy, że powoła się na przepis art. 183 § 1 k.p.k. i może uchylić się od odpowiedzi, powstaje realne zagrożenie nadużycia tej instytucji ${ }^{77}$.

Dokonując podsumowania czynionych powyżej rozważań, należy skonstatować, iż z aprobatą spotkał się pogląd Sądu Najwyższego, który stwierdził, że nie popełnia przestępstwa fałszywych zeznań, kto umyślnie składa nieprawdziwe zeznania dotyczące okoliczności mających znaczenie dla realizacji jego prawa do obrony. Prezentowaną koncepcję Sąd Najwyższy oparł na pozaustawowym kontratypie działania w zakresie prawa do obrony. Istotnie intencje Sądu Najwyższego były jak najbardziej słuszne i uzasadnione zaistniałymi okolicznościami faktycznymi. Należy jednak stwierdzić, iż chcąc uchylić powstałą w związku z przymusowym położeniem świadka kolizję między dobrem wymiaru sprawiedliwości a prawem do nieoskarżania samego siebie, nie można uciekać się do rozwiązań, które nie znajdują prawnego uzasadnienia. Za taką koncepcję uznaję proponowany przez Sąd Najwyższy pogląd o pozaustawowym kontratypie działania w zakresie uprawnień jako okoliczności wyłączającej przestępność czynu. Pomijając fakt, iż dochodzi tu do naruszenia zasady trójpodziału władzy poprzez przejęcie przez Sąd Najwyższy kompetencji ustawodawcy, to dokonana wykładnia jest wykładnią contra legem, wątpliwą ponadto pod względem moralnym. Faktycznego sprawcę przestępstwa przesłuchiwanego w charakterze świadka nie chronią gwarancje przynależne podejrzanemu. Kodeks postępowania karnego wyczerpująco wylicza sytuacje, w których pojawia się podejrzany, co wyklucza istnienie podejrzanego poza wypadkami wskazanymi w ustawie, a tym samym zakreśla najwcześniejszy moment, w którym określony uczestnik postępowania nabywa prawo do obrony. Powyższe pozostaje w zgodzie w regulacjami międzynarodowymi i krajowymi, które wykluczają rozszerzenie granic podmiotowych prawa do obrony na osoby inne aniżeli podejrzany. Ustawodawca dostrzegając powyższe mankamenty oraz chcąc zwiększyć stopień ochrony wymiaru sprawiedliwości przed wprowadzaniem $\mathrm{w}$ błąd organów procesowych w wyniku składania fałszywych zeznań, zawarł w art. 233 k.k. nową jednostkę redakcyjną - art. 233 \$1a, penalizując takie zachowania jak zeznawanie nieprawdy lub zatajanie prawdy z obawy przed odpowiedzialnością

${ }_{77}$ Postanowienie SN z dnia 8 lutego 2006 r., IV KK 394/05, LEX nr 333407; wyrok SA w Krakowie z dnia 11 maja 2009 r., II Aka 169/08, LEX nr 533944; A. GABERLE: Dowody w sadowym procesie karnym. Teoria i praktyka. Warszawa 2010, s. 319. 
karną. Jednoznaczne brzmienie przepisu wyklucza możliwość powołania się na działanie $\mathrm{w}$ ramach pozaustawowego kontratypu działania $\mathrm{w}$ zakresie prawa do obrony. W aktualnym stanie prawnym sprawca przestępstwa przesłuchiwany $\mathrm{w}$ charakterze świadka może jedynie skorzystać $\mathrm{z}$ prawa do odmowy odpowiedzi na pytanie $\mathrm{z}$ art. $183 \$ 1$ k.p.k. W rzeczywistości jednak takie prawo adresowane jest wyłącznie do świadka, a jego celem było wyjść naprzeciw konfliktowej sytuacji, w której ten może się znaleźć. Swoim zakresem nie obejmuje rzeczywistego sprawcy przestępstwa jako świadka specyficznego, wymagającego zwiększonej i szczególnej ochrony. W ocenie większości komentatorów instytucja z art. $183 \$ 1$ k.p.k. nie realizuje pokładanych $\mathrm{w}$ niej nadziei, jest instytucją martwą, w praktyce rzadko spotykaną. Aby poprawić sytuację osoby przesłuchiwanej, należałoby de lege ferenda wysuwać postulat obligatoryjnego pouczenia świadka o prawie z art. $183 \S 1$ k.p.k., tak aby każdy świadek miał świadomość, że to prawo istnieje i że może z niego skorzystać.

\section{Bibliografia}

\section{Literatura}

BanaszaK B.: Konstytucja Rzeczpospolitej Polskiej. Komentarz. Warszawa 2009.

BanaszaK B.: Konstytucja Rzeczypospolitej Polskiej. Komentarz. Warszawa 2012, LexisNexis.

BanaszaK B.: Prawo konstytucyjne. Warszawa 2001.

BECCARIA C.: O Przestępstwach i karach. Warszawa 1959.

BIELSKI M.: Wyłaczenie przestępności składania fałszywych zeznań $w$ zwiazku $z$ przystugujacym sprawcy czynu zabronionego prawem do obrony. CPKNP 2011, nr 15.

CIEŚLAK W.: Brak lojalności organu procesowego jako okoliczność wyłaczajaca odpowiedzialność karna za złożenie fatszywych zeznań. W: Reforma prawa karnego propozycje i komentarze. Ksiega pamiatkowa Profesor Barbary Kunickiej-Michalskiej. Red. J. Jakubowska-Hara, C. Nowak, J. Skupiński. Warszawa 2008.

Czabański J., Warchoє M.: Prawo do milczenia czy prawo do kłamstwa. Prok. i Pr. 2007, nr 12.

Doda Z., Gaberle A.: Dowody w procesie karnym. Orzecznictwo Sąu Najwyższego. Komentarz. T. I. Warszawa 1995.

DziaŁocha K.: Bezpośrednie stosowanie Konstytucji RP (stan doktryny prawa). W: Bezpośrednie stosowanie Konstytucji Rzeczypospolitej Polskiej. Red. IDEM. Warszawa 2005.

DzıAŁocha K.: Zasada bezpośredniego stosowania konstytucji $w$ dziedzinie wolności i praw obywateli. W: Obywatel - jego wolności i prawa. Zbiór studiów przygotowanych z okazji 10-lecia urzędu RPO. Red. B. OliwA-RADZIKOWSKA. Warszawa 1998.

FILAR M.: Glosa do uchwaty SN z dnia 20 września 2007 r., I KZP 26/2007. OSP 2008, nr 4. 
FILAR M.: Kodeks karny. Komentarz. Wyd. V. Red. M. FILAR. LEX Gamma.

GABERLE A.: Dowody w sadowym procesie karnym. Teoria i praktyka. Warszawa 2010.

Gierula I.: Kontratyp działania w granicach szczególnych uprawnień i obowiązków. Pal. 2013, nr 1-2.

GIEZEK J.: Glosa do postanowienia SN z 3 stycznia 2002 r., IV KKN 635/97. PiP 2002, nr 11.

GiezeK J., KŁąCzyŃsKa N., Łabuda G. W: Kodeks karny. Część ogólna. Komentarz. Red. J. GIEZEK. LEX Prestige 2012.

GruszeckA D.: Zasięg prawa do obrony w kontekście odpowiedzialności za fatszywe zeznania. CzPKiNP 2010, nr 2.

JęDRZEJEWSKI Z.: Nullum crimen sine lege i kontratypy a zasada jedności porzadku prawnego (jednolitej bezprawności). IN 2011, nr 1.

KaczMareK T.: O tzw. okolicznościach „wyłączających” bezprawność czynu. PiP 2008, nr 10.

KMIECIK R.: Glosa do uchwały SN z dnia 20 września 2007 r., I KZP 26/2007. PiP 2007, nr 12.

Konarska-Wrzosek V.: Kodeks karny. Komentarz. Red. V. KonarsKa-WrzoseK. LEX Gamma.

KOPER R.: Jawność rozprawy głównej a ochrona prawa do prywatności $w$ procesie karnym. Warszawa 2010.

KrajewsKi R.: Kontratyp karcenia matoletnich po wprowadzeniu prawnego zakazu stosowania wobec nich kar cielesnych. Pal. 2012, nr 1-2.

KwIATKOWsKi Z.: Glosa do uchwaty SN z dnia 20 czerwca 1991 r., I KZP 10/91. PS 1992, nr 7-8.

Labuda G., Razowski T., Kardas P.: Kodeks karny skarbowy. Komentarz. Kraków 2010.

LACH A.: Glosa do uchwaty SN z dnia 20 września 2007 r., I KZP 26/2007. LEX prestige.

ŁABNO-JABŁOŃSKA A.: Zasada bezpośredniego obowiq̨zywania konstytucyjnych praw $i$ wolności jednostki analiza prawno-porównawcza. W: Podstawowe prawa jednostki i ich sądowa ochrona. Red. L. WiśnIEWsKI. Warszawa 1997.

ŁoJEWSKI K.: Instytucja odmowy zeznań w polskim procesie karnym. Warszawa 1971.

MajEWsKi J.: Czy znamię podmiotowe (subiektywne) jest jedna z cech konstytutywnych kontratypu?. W: Okoliczności wyłaczajace bezprawność czynu. Materiaty IV Bielańskiego Kolokwium Karnistycznego. Red. J. Majewski. Toruń 2008.

MareK A.: Obrona konieczna w prawie karnym. Warszawa 1979.

Marszą K., Stachowiak S., ZgryzeK K. W: Proces karny. Red. K. MarszaŁ. Katowice 2005.

MączyŃsKi A.: Bezpośrednie stosowanie Konstytucji przez sądy. PiP 2000, nr 5.

Mozgawa M.: Kodeks karny. Komentarz aktualizowany. Red. M. Mozgawa. LEX Gamma.

PAPRZYCKI L.: Glosa do uchwaty SN z dnia 20 czerwca 1991, I KZP 12/91. Pal. 1992, nr 1-2.

PAWEeEK M.: Urojone prawo do obrony a odpowiedzialność za fatszywe zeznania. Prok. i Pr. 2009, nr 4. 
PlebaneK E.: Materialne określenie przestępstwa. Warszawa 2009 r., LEX Prestige.

PopŁawski H.: Działanie w granicach uprawnień i obowiązków jako okoliczność wyłączająca bezprawność czynu. NP 1967, nr 12.

PotUlski J.: Glosa do uchwaty SN z dnia 20 kwietnia 2007 r., I KZP 4/07. GSP 2008, nr 3.

RaJzman H.: Analogia in bonam partem $i$ zasada legalizmu $w$ prawie karnym. AUMCS 1966, vol. XIII, no. 2, Sectio G.

RaJZMAn H.: Zagadnienie „kontratypów” w projekcie kodeksu karnego PRL. PiP 1963, nr 3.

SAFIAN M., Bosek L.: Konstytucja RP. T. I: Komentarz do art. 1-86. Warszawa 2016, LexisNexis.

Sarnecki P.: Artykut 42. W: Konstytucja RP. Komentarz. T. III. Red. L. GarlickI. Warszawa 2003.

SANETRA W.: Bezpośrednie stosowanie Konstytucji RP w orzecznictwie Sadu Najwyższego. W: Bezpośrednie stosowanie Konstytucji Rzeczypospolitej Polskiej. Red. K. Dziatocha. Warszawa 2005.

SiweK M.: Glosa do uchwaty SN z dnia 26 kwietnia 2007 r., I KZP 4/2007. PS 2008, nr 3.

Sowiński P.K.: Prawo świadka do odmowy zeznań w procesie karnym. Warszawa 2004.

STEFAŃSKI R.A.: Glosa do uchwaty SN z dnia 26 kwietnia 2007 r., I KZP 4/07. OSP 2008, nr 3.

STEFAŃSKI R.A.: Komentarz do art. 191 k.p.k., Komentarz do ustawy z dnia 6 czerwca 1997 r. Kodeks postępowania karnego (Dz.U. 1997 r., Nr 89, poz 555), w zakresie przepisów o postępowaniu przygotowawczym. 2003. LEX Prestige.

StypuŁa S.: Fatszywe zeznania a prawo do obrony, Glosa do uchwaty SN z dnia 20 września 2007 r., I KZP 26/07. MP 2008, z. 15.

ŚwIECKI D. W: Kodeks postępowania karnego. T. I. Red. IDEM. LEX Gamma 2018.

TRZCIŃsKi J.: Funkcja prawna konstytucji socjalistycznej. Wrocław 1978.

Warchoє M.: Glosa do uchwaty SN z dnia 26 kwietnia 2007 r., I KZP 4/07. WPP 2007, nr 3.

WARYLEWSKi J.: Kontratypy wiosny. Pal. 199, nr 7-8.

WARYLEWSKI J.: Zasada ustawowej określoności przesłanek odpowiedzialności karnej a kontratypy pozaustawowe. W: Okoliczności wyłączajace bezprawność czynu. Materiały IV Bielańskiego Kolokwium Karnistycznego. Red. J. MajewsKi. Toruń 2008.

WĄSEK A.: Glosa do uchwaty SN z dnia 20 czerwca 1991 r., I KZP 12/91. WPP 1992, nr 3-4.

WĄSEK A.: Problematyka kontratypów przy przestępstwach nieumyślnych. Pal. 1988, nr 10.

Wolter W.: Funkcja błędu w prawie karnym. Warszawa 1965.

Wolter W.: W sprawie społecznego niebezpieczeństwa i bezprawności. NP 1956, nr 2.

WiLIŃski P.: Proces karny $w$ świetle konstytucji. Warszawa 2011.

WronkowsKa S.: W sprawie bezpośredniego stosowania Konstytucji. PiP 2001, nr 9. Zoll A.: W sprawie kontratypów. PiP 2009, nr 4. 


\section{Orzecznictwo}

Wyrok TK z dnia 31 stycznia 2001 r., P 4/99, OTK 2001, nr 1, poz. 5.

Wyrok TK z dnia 4 grudnia 2001 r., SK 18/00, OTK 2001, nr 8, poz. 256.

Wyrok TK z dnia 8 lipca 2003 r., P 10/02, OTK ZU nr 6/A/2003, poz. 62.

Wyrok TK z dnia 26 listopada 2003 r., SK 22/02, OTK ZU nr 9/A/2003, poz. 97.

Wyrok TK z dnia 3 listopada 2004 r., K 18/03, LEX nr 133746.

Wyrok TK z dnia 8 listopada 2004 r., K 38/03, LEX nr 133752.

Orzeczenie TK z dnia 20 października 1992 r., K 1/92, LEX nr 25221.

Uchwała SN z dnia 20 czerwca 1991 r., I KZP 12/91, LEX nr 20459.

Uchwała SN z dnia 26 kwietnia 2007 r., I KZP 4/07, LEX nr 244459.

Uchwała SN z dnia 20 września 2007 r., I KZP 26/07, LEX nr 298949.

Wyrok SN z dnia 30 grudnia 1972 r., Rw 1312/72, LEX nr 18582.

Wyrok SN z dnia 19 marca 1982 r., III KR 31/82, LEX nr 17432.

Wyrok SN z dnia 4 lipca 2000 r., WKN 12/00, LEX nr 438511.

Wyrok SN z dnia 3 stycznia 2002 r., IV KKN 635/97, LEX nr 52282.

Wyrok SN z dnia 30 października 2002 r., V CKN 1456/00, LEX nr 57237.

Wyrok SN z dnia 27 marca 2003 r., V CKN 1811/00, LEX nr 521816.

Wyrok SN z dnia 6 listopada 2003 r., II CK 184/02, LEX nr 1129611.

Wyrok SN z dnia 16 kwietnia 2004 r., I CK 291/03, OSNC 2005, nr 4, poz. 71.

Wyrok SN z dnia 24 czerwca 2004 r., III CK 536/02, LEX nr 172784.

Wyrok SN z dnia 24 kwietnia 2007 r., IV KK 127/07, LEX nr 293375.

Wyrok SN z dnia 3 grudnia 2008 r., V CSK 310/08, LEX nr 484695.

Wyrok SN z dnia 12 lutego 2009 r., III K 339/08, LEX nr 486545.

Wyrok SN z dnia 21 listopada 2014 r., III KK 348/14, LEX nr 1545153.

Wyrok SN z dnia 24 listopada 2015 r., II CSK 517/14, LEX nr 1940564.

Wyrok SN z dnia 30 czerwca 2009 r., V KK 25/09, LEX nr 512071.

Wyrok SN z dnia 17 października 2012 r., IV KK 99/12, LEX nr 1231601.

Wyrok SN z dnia 22 listopada 2012 r., V KK 265/12, LEX nr 1231653.

Postanowienie SN z dnia 8 lutego 2006 r., IV KK 394/05, LEX nr 333407.

Postanowienie SN z dnia 4 czerwca 2007 r., V KK 108/06, LEX nr 299215.

Postanowienie SN z dnia 22 września 2008 r., IV KK 241/08, LEX nr 464981.

Wyrok SA w Łodzi z dnia 19 czerwca 2001 r., II AKa 74/01, LEX nr 54981.

Wyrok SA we Wrocławiu z dnia 26 października 2006 r., II AKa 289/06, LEX nr 203385.

Wyrok SA w Krakowie z dnia 11 maja 2009 r., II Aka 169/08, LEX nr 533944.

Wyrok SO w Białymstoku z dnia 19 marca 2009 r., VIII Ka 63/09, LEX nr 1294025. Wyrok SO w Siedlcach z dnia 12 lipca 2013 r., II Ka 278/13, LEX nr 1717902.

Wyrok ETPC z dnia 20 października 1997 r., Serves c/a Francja, 20225/92, LEX nr 79567. 


\section{Źródła internetowe}

http://www.sejm.gov.pl/sejm8.nsf/druk.xsp?nr=207 [dostęp: 16.09.2017].

http://orka.sejm.gov.pl/Druki8ka.nsf/0/0F886B16326355A1C1257F5400517C7

1/\%24File/207-001.pdf [dostęp: 16.09.2017].

http://orka.sejm.gov.pl/Druki8ka.nsf/0/E4E18B486CF6499CC1257F5B0035420

F/\%24File/207-002.pdf [dostęp: 16.09.2017].

http://orka.sejm.gov.pl/Druki8ka.nsf/0/8A270DCCB24D2E31C1257F5E00490

5B5/\%24File/207-003.pdf [dostęp: 16.09.2017].

http://orka.sejm.gov.pl/Druki8ka.nsf/0/4057EAF4004A8D08C1257F64005B

EDCB/\%24File/207-004.pdf [dostęp: 16.09.2017].

http://orka.sejm.gov.pl/Druki8ka.nsf/0/CC7AB6DB0551BFC0C1257F6B003F

CB99/\%24File/207-005.pdf [dostęp: 16.09.2017]. 